\title{
The Network for the Detection of Atmospheric Composition Change (NDACC): history, status and perspectives
}

\author{
Martine De Mazière ${ }^{1}$, Anne M. Thompson ${ }^{2}$, Michael J. Kurylo ${ }^{3}$, Jeannette D. Wild ${ }^{4}$, Germar Bernhard ${ }^{5}$, \\ Thomas Blumenstock $^{6}$, Geir O. Braathen ${ }^{7}$, James W. Hannigan ${ }^{8}$, Jean-Christopher Lambert ${ }^{1}$, Thierry Leblanc ${ }^{9}$, \\ Thomas J. McGee $^{2}$, Gerald Nedoluha ${ }^{10}$, Irina Petropavlovskikh ${ }^{11}$, Gunther Seckmeyer ${ }^{12}$, Paul C. Simon ${ }^{1}$, \\ Wolfgang Steinbrecht ${ }^{13}$, and Susan E. Strahan ${ }^{3}$ \\ ${ }^{1}$ Royal Belgian Institute for Space Aeronomy (BIRA-IASB), Brussels, 1180, Belgium \\ ${ }^{2}$ NASA-Goddard Space Flight Center, Earth Sciences Division, Greenbelt, MD 20771-0001, USA \\ ${ }^{3}$ Universities Space Research Association, Goddard Earth Science, Technology and Research, \\ NASA-Goddard Space Flight Center, Greenbelt, MD 20771-0001, USA \\ ${ }^{4}$ INNOVIM, LLC, Greenbelt, MD; Climate Prediction Center, NOAA Center for Weather and Climate Prediction, \\ College Park, MD 20740, USA \\ ${ }^{5}$ Biospherical Instruments, Inc., San Diego, CA 92110-2621, USA \\ ${ }^{6}$ Institute for Meteorology and Climate Research (IMK), Karlsruhe Institute of Technology (KIT), \\ 76021 Karlsruhe, Germany \\ ${ }^{7}$ Atmospheric Environment Research Division, Research Department, World Meteorological Organization \\ (WMO), Geneva, Switzerland \\ ${ }^{8}$ Atmospheric Chemistry Observations and Modeling, National Center for Atmospheric Research, \\ Boulder, CO 80305-5602, USA \\ ${ }^{9}$ Table Mountain Facility, Jet Propulsion Laboratory, Wrightwood, CA 92397-0367, USA \\ ${ }^{10}$ Remote Sensing Division, Naval Research Laboratory, Washington, DC 20375-5351,USA \\ ${ }^{11}$ NOAA Earth System Research Laboratory, Global Monitoring Division, Boulder, CO 80305-3328, USA \\ ${ }^{12}$ Institute for Meteorology and Climatology, University of Hannover, 30419 Hannover, Germany \\ ${ }^{13}$ Deutscher Wetterdienst, Meteorologisches Observatorium, 82383 Hohenpeissenberg, Germany
}

Correspondence: Martine De Mazière (martine.demaziere@aeronomie.be)

Received: 30 April 2017 - Discussion started: 14 August 2017

Revised: 22 February 2018 - Accepted: 23 February 2018 - Published: 11 April 2018

\begin{abstract}
The Network for the Detection of Atmospheric Composition Change (NDACC) is an international global network of more than 90 stations making high-quality measurements of atmospheric composition that began official operations in 1991 after 5 years of planning. Apart from sonde measurements, all measurements in the network are performed by ground-based remote-sensing techniques. Originally named the Network for the Detection of Stratospheric Change (NDSC), the name of the network was changed to NDACC in 2005 to better reflect the expanded scope of its measurements. The primary goal of NDACC is to establish long-term databases for detecting changes and trends in the chemical and physical state of the atmosphere (meso-
\end{abstract}

sphere, stratosphere, and troposphere) and to assess the coupling of such changes with climate and air quality. NDACC's origins, station locations, organizational structure, and data archiving are described. NDACC is structured around categories of ground-based observational techniques (sonde, lidar, microwave radiometers, Fourier-transform infrared, UVvisible DOAS (differential optical absorption spectroscopy)type, and Dobson-Brewer spectrometers, as well as spectral UV radiometers), timely cross-cutting themes (ozone, water vapour, measurement strategies, cross-network data integration), satellite measurement systems, and theory and analyses. Participation in NDACC requires compliance with strict measurement and data protocols to ensure that the net- 
work data are of high and consistent quality. To widen its scope, NDACC has established formal collaborative agreements with eight other cooperating networks and Global Atmosphere Watch (GAW). A brief history is provided, major accomplishments of NDACC during its first 25 years of operation are reviewed, and a forward-looking perspective is presented.

\section{Introduction}

\subsection{Atmosphere composition issues in the 1970s and 1980s: scoping an international network}

When the scientific community looks back on the origins of research into measuring and understanding changes in global chemical composition, two phenomena are usually mentioned. One relates to regional air quality and the first characterization of photochemical "smog." Historians cite reports of threatening air quality as early as the 19th century but generally date studies of air pollution back to the 1950s when the chemical and physical processes leading to unhealthy urban environments were first formulated. Second, during the 1960s and 1970s scientists began to consider chemical threats to the atmosphere as a whole. This was inspired by views of our planet from space and was given a boost from measurement projects that were initiated during the 19571958 International Geophysical Year (IGY). During the IGY, background ground-based monitoring stations began to measure in situ surface concentrations of gases like carbon dioxide and methane and total column ozone together with related constituents, many of which were heavily concentrated in the stratosphere. Unlike many short-lived chemical pollutants, carbon dioxide and lower-stratospheric ozone have long lifetimes and more uniform distributions globally. Furthermore, they are related to the radiative properties of the atmosphere. Water vapour and carbon dioxide are primary greenhouse gases, and the thickness of the ozone column abundance determines the amount of ultraviolet (UV) radiation at the earth's surface.

Concerns about global ozone intensified with the realization that stratospheric ozone chemistry included catalytic cycles involving reactive halogens, nitrogen, and hydrogen (Bates and Nicolet, 1950; Crutzen, 1974a; Stolarski and Cicerone, 1974; Molina and Rowland, 1974). Early spectroscopic balloon measurements confirmed the presence of trace species like $\mathrm{NO}_{2}, \mathrm{HNO}_{3}$, and $\mathrm{HCl}$ (Murcray et al., 1968, 1973; Ackerman et al., 1974; Williams et al., 1976). With expanding space programs and proposals for large fleets of supersonic commercial aircraft, theoretical studies looked at possible threats to stratospheric ozone from rocket and aviation exhaust (Johnston, 1971). Scientists were also beginning to consider the growing use of chlorofluorocarbons (CFCs) in myriad applications (Stolarski et al., 1974; Cicerone et al., 1974). Shortly thereafter, laboratory studies that measured the rates of free radical reactions, coupled with simple models, predicted global damage to ozone in the middle and upper stratosphere due to aviation exhaust emissions and to industrial halogenated compounds. Even the relatively inert $\mathrm{N}_{2} \mathrm{O}$, a byproduct of nitrogen fertilizers in wide use, would destroy ozone if it upset the natural balance of reactive nitrogen in the stratosphere.

Following a 1971 meeting of atmospheric scientists, the US "Stratospheric Protection Act of 1971", set up a Federal program of stratospheric research that was to report to the Congress within 2 years (Senate Congressional Record, 21 September 1971). In the fall of 1971, Congress assigned the US Department of Transportation (DOT) to conduct the 2year Climatic Impact Assessment Program (CIAP), an international effort to assess the impact of climatic changes that might result from the introduction of propulsion effluents into the stratosphere (Grobecker, 1974). In 1972 the United Nations Conference on the Human Environment was held; its report (http://www.un-documents.net/aconf48-14r1.pdf; last access: 2 April 2018) is considered a classic in the history of atmospheric chemistry. As a result, programs like the French-UK COVOS (Comité d'Études sur les Conséquences des Vols Stratosphériques) were initiated to assess the potential damage to future stratospheric ozone levels. The US National Aeronautics and Space Administration (NASA) was given a long-term mandate in its FY (fiscal year) 1976 authorization bill to perform research concerned with the possible depletion of the ozone layer (covering all aspects of stratospheric chemistry, from laboratory investigations of chemical reaction rates, to ground-based and in situ measurements of trace gases and computer modelling to simulate the present atmosphere and to predict the future atmosphere). This mandate to perform research on the depletion of the Earth's ozone layer soon led to the establishment of NASA's Upper Atmosphere Research Program (UARP). Numerous research projects supported by UARP complemented the first satellite measurements of global ozone by backscatter UV techniques (BUV) that started with the USSR Kosmos missions in 1964 1965 (Iozenas et al., 1969) and NASA's Orbiting Geophysical Observatory in 1967-1969 (Anderson et al., 1969) and BUV on Nimbus 4 in 1970-1975 (Heath et al., 1973). The first European atmospheric research from space was based on solar occultation and limb emission instruments operated on the Spacelab laboratory module, the latter built in cooperation between NASA and the European Space Research Organization (ESRO), which became the European Space Agency (ESA) in May 1975. After the pioneering flight of Spacelab 1 in 1983, 21 more Spacelab missions occurred between 1983 and 1998, among which there were three Atmospheric Laboratory for Application and Science (ATLAS) space shuttle missions in 1992-1994 (Miller et al., 1994). The ATLAS missions carried a set of instruments provided by the US and Europe, some in collaboration with Japan, and were occasionally complemented with additional instru- 
ments operated on free-flying satellites launched from the space shuttle (ESA's EURECA (European Retrievable Carrier) and the German ASTRO-SPAS (Astronomical Shuttle Pallet Satellite)). The US National Oceanic and Atmospheric Administration's (NOAA's) Upper Air Branch of the National Weather Service also began analyses of stratospheric measurements from ground-based and satellite data in the late 1970s.

The discovery of the Antarctic ozone hole (Farman et al., 1985) transformed atmospheric chemistry and made it clear that more detailed stratospheric observations were needed to help determine its origin. Responding to predictions of ozone depletion in the mid- to upper stratosphere (Molina and Rowland, 1974; Crutzen, 1974b; Cadle et al., 1975), many countries had banned CFCs from certain applications in the 1970s. Nevertheless, the morphology of Antarctic ozone loss and its severity were beyond any causal theories of the time. Ground-based and airborne campaigns conducted in 1986 and 1987 provided evidence for a direct link between ozone depletion in the Antarctic stratosphere and catalytic halogen reaction cycles and indicated that the basic processes responsible for polar ozone loss involved heterogeneous reactions that took place on atmospheric ice particles that formed at temperatures about $3-4 \mathrm{~K}$ below the ice frost point (i.e. at approximately $185 \mathrm{~K}$ ). Over the next decade, the results from subsequent aircraft campaigns in the Arctic demonstrated the vulnerability of the stratospheric ozone layer in both polar regions as well as at midlatitudes. However, the mere observation of Antarctic ozone depletion in austral spring, together with considerable advances in the technology required to measure other stratospheric species from the ground, suggested that it was time to consider assembling a more detailed stratospheric monitoring program. At that same time, the 1985 International Vienna Convention for the Protection of the Ozone Layer gave a political mandate for comprehensive long-term monitoring of the ozone layer. Thus, in March 1986 NASA, NOAA, and the Chemical Manufacturers Association (CMA) convened a workshop in Boulder (Colorado, US) to ascertain the feasibility of developing a longterm observational network specifically designed to provide the earliest possible detection of changes in the composition and structure of the stratosphere and, more importantly, the means to understand the causes of those changes. Measurement priorities and goals were defined, station placements were considered, and potential instrumentation was evaluated. Many instruments were under development (ozone lidar (light detection and ranging)); some were demonstrated (microwave radiometry for $\mathrm{H}_{2} \mathrm{O}$, UV-visible spectrometry for $\mathrm{NO}_{2}$, Fourier-transform infrared spectrometry (FTIR) for $\mathrm{HCl}$ ) and some proposed (microwave for $\mathrm{N}_{2} \mathrm{O}$, FTIR for several more species). However, only the Dobson ozone spectrometer was fully operational at that time. At a 1989 meeting in Geneva, NASA, NOAA, and the World Meteorological Organization (WMO) convened a forum at which several international agencies and institutions participated. At that meeting the actual organizational structure of the Network for the Detection of Stratospheric Change (NDSC) was formalized (Kurylo and Solomon, 1990). Annual Steering Committee meetings for the network commenced in 1990; in 1991 and after 5 years of planning the NDSC began official operations. These international planning meetings (Table 1) had led to the realization that such a research and monitoring program needed to be global. Thus, NDSC represented from its beginning a consortium of countries and sponsoring organizations, with endorsement from the United Nations Environment Programme (UNEP), the WMO, and the International Ozone Commission $\left(\mathrm{IO}_{3} \mathrm{C}\right)$, a body of the IUGG/IAMAS (International Union of Geodesy and Geophysics/International Association of Meteorology and Atmospheric Science).

The stratospheric ozone focus was an obvious integrating theme during the early NDSC years. However, the scope of measurement requirements was broadened by regular collaboration with field measurement programs and experiments, interdisciplinary data analysis, and modelling activities and assessments. Therefore, in 2005, NDSC changed its name to NDACC (Network for the Detection of Atmospheric Composition Change) to reflect the broadened scope. Many trace gases measured in NDACC and by its partners (see Sect. 2.1) are as important to climate issues and/or air quality as they are to ozone depletion, as recognized in today's NDACC objectives, listed as follows:

- to establish long-term databases for detecting changes and trends in atmospheric composition and to understand their impacts on the mesosphere, stratosphere, and troposphere;

- to establish scientific links and feedbacks between changes in atmospheric composition, climate, and air quality;

- to validate atmospheric measurements from other platforms (i.e. satellites, aircraft, and ground-based platforms);

- to provide critical data sets to help fill gaps in satellite observations;

- to provide collaborative support to scientific field campaigns and to other chemistry and climate-observing networks; and

- to provide validation and development support for atmospheric models.

Hereafter, we will use the current acronym NDACC whenever we refer to the network.

\subsection{Structure of overview paper}

NDACC has provided a unique, enduring framework for the international community to make long-term ground-based 
Table 1. NDSC/NDACC meeting history and key actions and Steering Committee (SC) Chair and Co-Chair elections.

\begin{tabular}{|c|c|c|}
\hline Year & Location & Actions \\
\hline 1986 & Boulder, CO, USA & Concept and feasibility of the network evaluated \\
\hline 1989 & Geneva, Switzerland & $\begin{array}{l}\text { Managerial and organizational structure of the NDSC formalized; SC Chair } \\
\text { (Michael J. Kurylo) and Vice-Chair (R. A. "Tony" Cox) elected }\end{array}$ \\
\hline 1990 & Washington, DC, USA & $\begin{array}{l}\text { 1st annual NDSC SC meeting; five primary stations designated covering both hemi- } \\
\text { spheres }\end{array}$ \\
\hline 1991 & Abingdon, UK & $\begin{array}{l}\text { 2nd annual SC meeting; official network operations began, endorsed by UNEP, the } \\
\text { WMO, and } \mathrm{IO}_{3} \mathrm{C} \text {; complementary measurement opportunities discussed; data protocol } \\
\text { finalized; official NDSC Data Host Facility (DHF) established at NOAA with mirroring } \\
\text { at the British Atmospheric Data Center (BADC) and at the Norwegian Institute for Air } \\
\text { Research (NILU) }\end{array}$ \\
\hline 1992 & Paris, France & $\begin{array}{l}\text { 3rd annual SC meeting; evaluation of new instruments; complementary sites desig- } \\
\text { nated; NDSC Data Host Facility (DHF) begins archiving data from multiple sites }\end{array}$ \\
\hline 1993 & Wrightwood, CA US & $\begin{array}{l}\text { 4th annual SC meeting; "Instrument Validation Policy" document finalized; new com- } \\
\text { plementary stations approved; potential theory and analysis investigators identified; } \\
\text { protocol for SC elections and appointments finalized; Mike Kurylo re-elected to 3-year } \\
\text { term as SC Chair }\end{array}$ \\
\hline 1994 & Queenstown, NZ & $\begin{array}{l}\text { 5th annual SC meeting; "Protocol for Instrument Intercomparisons" finalized; spectral } \\
\text { UV measurements added to network }\end{array}$ \\
\hline 1995 & Leuven, Belgium & $\begin{array}{l}\text { 6th annual SC meeting; additional complementary measurement activities approved; } \\
\text { NDSC website announced; instrument-specific validation appendices added to "Vali- } \\
\text { dation Protocol"; Rudy Zander elected as SC Vice-Chair, replacing Tony Cox, who had } \\
\text { resigned; Mike Kurylo re-elected as SC Chair; }\end{array}$ \\
\hline 1996 & Waikoloa, HI, USA & $\begin{array}{l}\text { 7th annual SC meeting; formal presentations by instrument working groups represent- } \\
\text { ing the various NDSC-designated instrument types and by the Satellite and the Theory } \\
\text { and Analysis working groups; Mike Kurylo re-elected to 3-year term as SC Chair }\end{array}$ \\
\hline 1997 & Spitsbergen, Norway & $\begin{array}{l}\text { 8th annual SC meeting; status of and plans for NDSC mobile instrument reviewed; } \\
\text { Dobson/Brewer Instrument Working Group added }\end{array}$ \\
\hline 1998 & Réunion Island, France & $\begin{array}{l}\text { 9th annual SC meeting; endorsement given to develop a new observatory site at Maïdo; } \\
\text { Rudy Zander re-elected to 3-year term as SC Vice-Chair }\end{array}$ \\
\hline 1999 & Sapporo, Japan & $\begin{array}{l}\text { 10th annual SC meeting; designations of primary and alternate working group rep- } \\
\text { resentatives changed to co-representatives; SC Chair and Vice-Chair positions re- } \\
\text { designated as co-chairs; Mike Kurylo elected to 3-year term as SC Co-Chair; } \\
\text { Rudy Zander's position changed from SC Vice-Chair to SC Co-Chair; new ex officio } \\
\text { positions established on the SC }\end{array}$ \\
\hline 2000 & Thun, Switzerland & $\begin{array}{l}\text { 11th annual SC meeting; annual station report forms standardized; } 10 \text {-year NDSC An- } \\
\text { niversary Symposium to be scheduled in } 2001\end{array}$ \\
\hline 2001 & Arcachon, France & $\begin{array}{l}\text { 12th annual SC meeting held in conjunction with an international symposium celebrat- } \\
\text { ing } 10 \text { years of NDSC operations; Rudy Zander re-elected as SC Co-Chair }\end{array}$ \\
\hline 2002 & Toronto, Canada & $\begin{array}{l}\text { 13th annual SC meeting; special NDSC session to be conducted at the } 2003 \text { joint EGS- } \\
\text { AGU-EUG (European Geophysical Society-American Geophysical Union-European } \\
\text { Union of Geosciences) meeting; draft of first NDSC Newsletter presented; Rudy Zan- } \\
\text { der resigned as NDSC Co-Chair due to his university retirement; Paul Simon elected to } \\
\text { serve the remaining } 2 \text { years of Rudy Zander's term; Mike Kurylo re-elected to 3-year } \\
\text { term as SC Co-Chair }\end{array}$ \\
\hline 2003 & Wellington, NZ & $\begin{array}{l}\text { 14th annual SC meeting; final version of NDSC Newsletter presented; creation of an } \\
\text { NDSC leaflet discussed }\end{array}$ \\
\hline 2004 & Andøya, Norway & $\begin{array}{l}\text { 15th annual SC meeting; discussions on how to make NDSC connections to global } \\
\text { change and the troposphere more visible; with the expiration of Paul Simon's position } \\
\text { as SC Co-Chair, he was named to an ex officio position on the SC, and Geir Braathen } \\
\text { was elected as the new SC Co-Chair }\end{array}$ \\
\hline 2005 & Tenerife, Spain & $\begin{array}{l}\text { 16th annual SC meeting; Mike Kurylo was re-elected as SC Co-Chair; the name of } \\
\text { NDSC changed to the Network for the Detection of Atmospheric Composition Change } \\
\text { (NDACC) to better reflect the expanded focus of its measurements }\end{array}$ \\
\hline 2006 & OHP, France & $\begin{array}{l}\text { 17th annual SC meeting; report on water vapour measurement techniques presented; } \\
\text { options for a new NDACC logo discussed }\end{array}$ \\
\hline 2007 & Waikoloa, HI, USA & $\begin{array}{l}\text { 18th annual SC meeting; discussions on how to make external network affiliations more } \\
\text { meaningful; Geir Braathen re-elected as SC Co-Chair }\end{array}$ \\
\hline
\end{tabular}


Table 1. Continued.

\begin{tabular}{|c|c|c|}
\hline Year & Location & Actions \\
\hline 2008 & $\begin{array}{l}\text { Kangerlussuaq and Ilulis- } \\
\text { sat, Greenland }\end{array}$ & $\begin{array}{l}\text { 19th annual SC meeting; primary and complementary site/station designations re- } \\
\text { placed by NDACC-approved measurement site/station; NDACC cooperating net- } \\
\text { work affiliation established; tropospheric water vapour lidars and water vapour son- } \\
\text { des approved as NDACC techniques; Mike Kurylo re-elected as SC Co-Chair }\end{array}$ \\
\hline 2009 & Geneva, Switzerland & 20th annual SC meeting; five initial cooperating network affiliations approved \\
\hline 2010 & Queenstown, NZ & $\begin{array}{l}\text { 21st annual SC meeting; sixth cooperating network added; Symposium planned to } \\
\text { commemorate } 20 \text { years of NDSC/NDACC observations; Geir Braathen accepted re- } \\
\text { election as SC Co-Chair }\end{array}$ \\
\hline 2011 & Réunion Island, France & $\begin{array}{l}\text { 22nd annual SC meeting held at NDSC/NDACC } 20 \text { years Anniversary symposium; } \\
\text { seventh cooperating network added; rapid delivery data added to the DHF; Stu- } \\
\text { art McDermid elected as SC Co-Chair, replacing Mike Kurylo, who stepped down }\end{array}$ \\
\hline 2012 & Garmisch, Germany & $\begin{array}{l}\text { 23rd annual SC meeting; opening of new Maïdo Observatory on Réunion Island } \\
\text { announced; Water Vapor Theme Group announced publication of ISSI scientific re- } \\
\text { port on "Monitoring Atmospheric Water Vapour"; role of NDACC measurements in } \\
\text { the SPARC/IO }{ }_{3} \text { C/IGACO/NDACC (SI2N) Initiative on Past Changes in the Vertical } \\
\text { Distribution of Ozone highlighted }\end{array}$ \\
\hline 2013 & Frascati, Italy & $\begin{array}{l}\text { 24th annual SC meeting; Martine De Mazière elected as SC Co-Chair, replacing } \\
\text { Geir Braathen, who stepped down }\end{array}$ \\
\hline 2014 & Brussels, Belgium & $\begin{array}{l}\text { 25th annual SC meeting; Anne M. Thompson elected as SC Co-Chair, replacing } \\
\text { Stuart McDermid, who stepped down }\end{array}$ \\
\hline 2015 & La Jolla, CA, USA & $\begin{array}{l}\text { 26th annual SC meeting; Theory and Analysis Working Group announced the avail- } \\
\text { ability of model support files for several instrument types }\end{array}$ \\
\hline 2016 & Bremen, Germany & $\begin{array}{l}\text { 27th annual SC meeting; } 25 \text { years of successful NDSC/NDACC measurements and } \\
\text { analyses highlighted in a feature article in NASA's Earth Observer newsletter; Mar- } \\
\text { tine De Mazière re-elected for a second term as Co-Chair }\end{array}$ \\
\hline 2017 & Boulder, CO, USA & $\begin{array}{l}\text { 28th annual SC meeting; Anne M. Thompson re-elected for a second term as Co- } \\
\text { Chair }\end{array}$ \\
\hline
\end{tabular}

measurements of atmospheric composition on a global scale. To celebrate the 10th and 20th anniversaries of NDACC, symposia highlighting the network scientific achievements were held in 1991 (Arachon, France) and in 2011 (Réunion Island), respectively. For the 25th anniversary NDACC decided to publish a feature article in The Earth Observer (Kurylo et al., 2016) and to assemble an inter-journal special issue in the journals Atmospheric Chemistry and Physics, Atmospheric Measurement Techniques, and Earth System Science Data. This paper is the introductory paper for this special issue. The organizational structure and workings of NDACC, remarkably adaptable and important to its success, are described in Sect. 2. Highlights of scientific accomplishments of NDACC over the past 25 years appear in Sect. 3 . Section 4 anticipates further developments in network configurations and Sect. 5 is a perspective on the future of NDACC as we look at current issues in global atmospheric composition and dynamics.

\section{The organization and workings of NDACC}

\subsection{Scope of measurements, stations, and objectives}

Figure 1 illustrates the major atmospheric variables (constituents and physical parameters) that are measured within NDACC in order to achieve the full scope of network objectives listed in Sect. 1. Included are column and vertical profile measurements that provide complementarity to satellite measurements of the same variable. For example, UV-visible DOAS (differential optical absorption spectroscopy)-type instruments, which are shown along with Brewer and Dobson spectrometers, have kept myriad ozone satellite instruments calibrated and cross-calibrated since the start of NDACC and even 2 decades before.

The right side of Fig. 1 depicts the vertical resolution of NDACC techniques used to measure various constituents throughout the troposphere and stratosphere up to the lower mesosphere. Note the use of microwave, lidar, and FTIR along with balloon-borne soundings that, in many locations, offer the greatest vertical resolution up to the middle stratosphere.

A few more species are measured, e.g. HCFC-142b at some FTIR stations, and this list of species keeps increasing with time, in keeping with the evolution of the measurement 


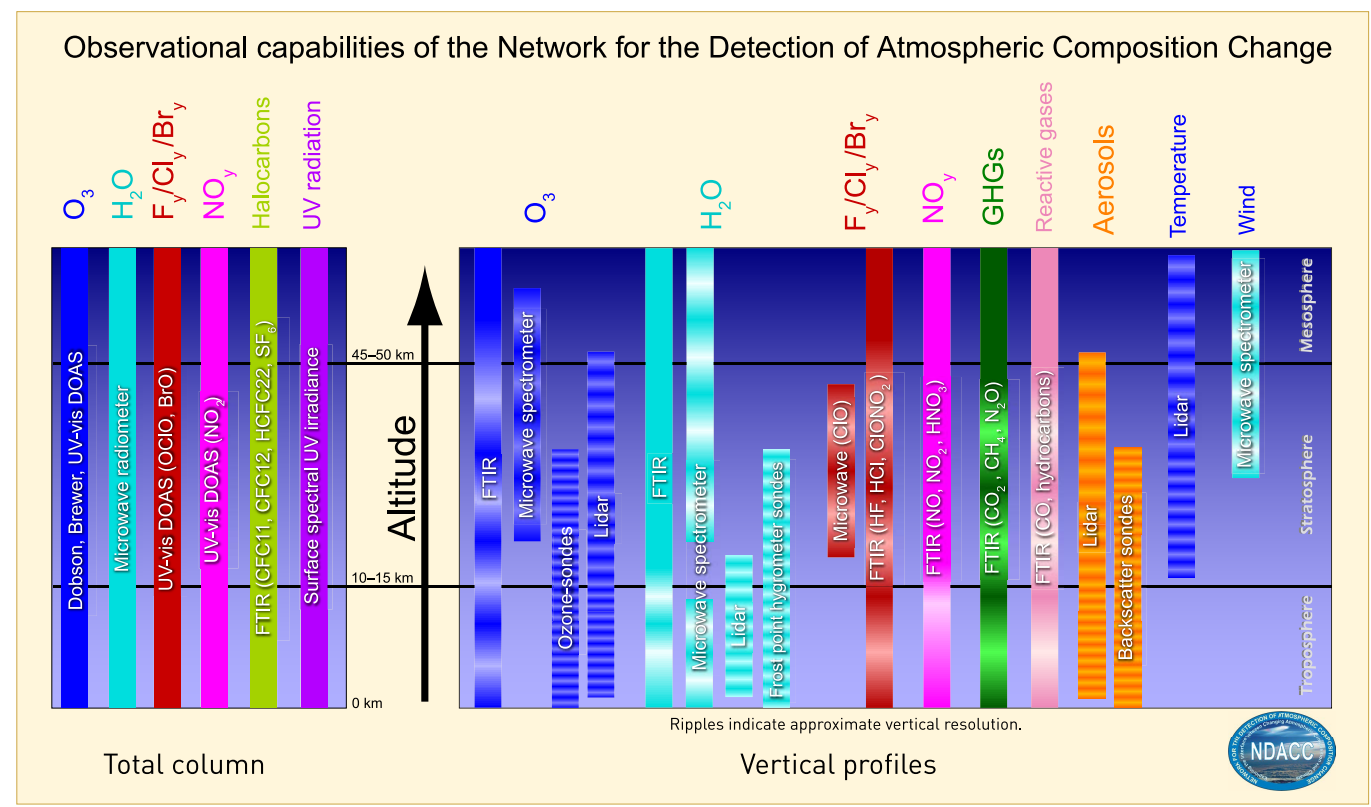

Figure 1. NDACC measurement capabilities, including species and parameters measured, instrumental measurement techniques, and each measurement's approximate vertical resolution (indicated by the ripple).

techniques and of the research interests and with the changing abundances of some species.

Very soon, the UV-visible MAXDOAS (Multi-AXis DOAS) technique will be included in the list of certified NDACC measurement techniques, enabling the observation of additional species like glyoxal as well as the observation of lower-tropospheric profiles of $\mathrm{NO}_{2}, \mathrm{HCHO}$, and $\mathrm{O}_{3}$ (Kreher et al., 2018).

The full list of species for which data are available in the NDACC database are given in Box 1; for some species not listed in Box 1, data are available upon request from the individual principal investigators (PIs).

Box 1. Full list of variables (in alphabetical order) for which data are available in the NDACC database at the moment of this publication.

Aerosol, $\mathrm{BrO}, \mathrm{C}_{2} \mathrm{H}_{2}, \mathrm{C}_{2} \mathrm{H}_{4}, \mathrm{C}_{2} \mathrm{H}_{6}, \mathrm{CCl}_{2} \mathrm{~F}_{2}, \mathrm{CCl}_{3} \mathrm{~F}, \mathrm{CH}_{3} \mathrm{OH}, \mathrm{CH}_{4}$,
$\mathrm{CHF}_{2} \mathrm{Cl}$, chlorine, $\mathrm{ClONO}_{2}, \mathrm{CO}, \mathrm{CO}_{2}, \mathrm{COF}_{2}, \mathrm{H}_{2} \mathrm{CO}, \mathrm{H}_{2} \mathrm{O}$ and
isotopologues, $\mathrm{HCHO}, \mathrm{HCl}, \mathrm{HCN}, \mathrm{HCOOH}, \mathrm{HF}, \mathrm{HNO}_{3}, \mathrm{~N}_{2} \mathrm{O}$,
$\mathrm{NH}_{3}, \mathrm{NO}, \mathrm{NO}_{2}, \mathrm{OClO}, \mathrm{OCS}$, ozone, $\mathrm{SF}_{6}$, temperature,
tropospheric ozone, spectral UV irradiance, wind

An essential element of NDACC is the rigour of the measurements and their analyses, which since the first days of NDACC have been ensured by regular instrument and algorithm validation and intercomparison campaigns. A key ingredient of NDACC has been the establishment of written protocols detailing validation procedures, expectation of instrument and measurement quality standards, and data analysis and reporting standards (http://www.ndaccdemo.org/ data-documents/protocols/; last access: 2 April 2018). This quality assurance lends considerable credence to the ground- based record which NDACC has contributed to all the quadrennial WMO Scientific Assessments of Ozone Depletion (1991 to present).

The current map with certified active NDACC stations appears in Fig. 2. The 1986 workshop envisioned an initial network structure of six primary stations, most of which would consist of several sites and host several instruments. An additional site at Table Mountain (California) was to be a "test site" and, thus, became the first complementary site in the network. The established stations at Observatoire de Haute Provence (OHP), France, and Jungfraujoch, Switzerland, and at Mauna Loa, Hawaii, were identified as principal contributors to the primary stations (Alpine Station and Hawaii Station, respectively). In 1991, five primary stations were actually established: Arctic, Alpine, Hawaii, Lauder New Zealand, and Antarctic Station. It was anticipated that numerous complementary stations, at which a smaller number of network-approved instruments were in operation or at which the measurement commitment was for a shorter period of time, would augment these primary stations. In 2008 the NDACC Steering Committee (SC) decided to remove the "primary" and "complementary" designations of NDACC measurement sites/stations since their use was leading to some confusion and occasional misunderstanding. For example, some complementary stations had built up suites of instruments that were more comprehensive than those at some of the primary stations and many complementary stations had measurement commitments that were just as longterm as those at primary stations. Further, the designations had occasionally been misinterpreted to imply that the mea- 


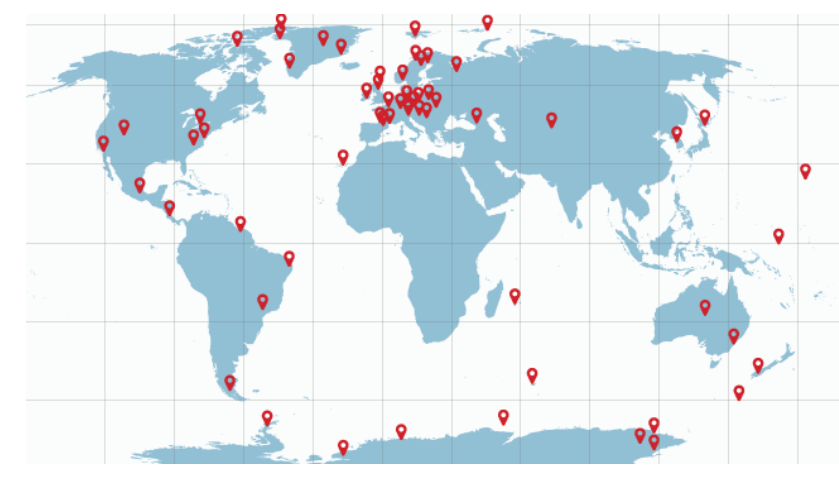

Figure 2. Map of currently active NDACC stations.

surements at and data from complementary stations were of lesser quality than those at primary stations, whereas the requirements to become affiliated with NDACC were identical for the two categories.

In addition to the stations in Fig. 2, some new stations (in China, Africa, South America, etc.) have applied for affiliation to NDACC. While they are in the process of certification, during which the compliance with the NDACC protocols is verified, they have the status of "candidate stations" and do not appear on the map of active stations in Fig. 2.

\subsection{Network structure and workings}

Figure 3 illustrates the organizational structure of NDACC. Its basic structure has remained unchanged over 25 years, but the details of SC composition, working and theme groups, and partners and the Data Handling Facility (DHF; Sect. 2.3) have evolved over time. The present SC is led by two CoChairs; Table 1 lists the co-chairs who have served since 1991 together with a history of SC meetings and some ensuing actions. There are seven permanent instrument working groups (Fig. 3) in NDACC, organized around instrument types: Dobson and Brewer, FTIR, lidar, microwave, sondes, spectral UV, or UV-visible spectrometers. Two additional permanent working groups, on Satellites and on Theory and Analysis, contribute cross-cutting activities connected to multiple instrument types and liaise with data user communities. Two representatives from each of the nine working groups are members of the NDACC SC.

The Steering Committee also identified the need for four theme groups whose activities are typically of more limited duration and are organized around specific foci that may be relevant to several instrument working groups. Therefore, the theme groups often involve participation from representatives from several instrument working groups and benefit from synergies between measurement techniques to address their foci. For example, a Water Vapor Theme Group was established in 2006 to assess the accuracy of various water vapour measurement techniques and resulted in an ISSI (International Space Science Institute) publication (Kämpfer,
2013). More recently the Water Vapor Theme Group has been developing a network-wide measurement strategy for atmospheric water vapour. Although its initial instrument orientation focused on frost point sondes, the strategy will coordinate all current NDACC water vapour measurements (e.g. lidar, microwave, FTIR).

Since its beginning, NDACC recognized the importance of new measurement capabilities and of existing capabilities whose heritage was developed externally to the network as well as the strong scientific benefits of fostering collaborative measurement, analysis, and quality assurance activities with other networks that were operating independently of NDACC and were collecting high-quality data. Accordingly, cooperating network affiliations with NDACC were initiated (Table 1) with data-sharing protocols. In 2009 the first five cooperating networks were formalized. There are eight cooperating networks at this time (Table 2) and a representative of each one serves on the NDACC SC.

Products useful for quantifying the feedbacks between climate change and atmospheric composition will require careful integration of information from sondes with instruments that supply integrated column values or low-resolution vertical profiles. In this effort, NDACC may expand its relationship with the sounding-focused GCOS (Global Climate Observing System) Reference Upper Air Network (GRUAN).

\subsection{Data handling facility}

Initially the data from the five original primary and complementary stations were housed on a VAX/Virtual Memory System (VAX/VMS) system with access solely to the NDACC data providers. Mirrors of the NDACC database were housed at the British Atmospheric Data Centre (BADC) and the Norwegian Institute for Air Research (NILU) to provide offsite backup and distributed data access for international partners. The file format chosen in collaboration with the Upper Atmosphere Research Satellite (NASA) (UARS), EASOE (European Arctic Stratospheric Ozone Experiment; European Commission, 1997), and other international projects was the simple ASCII (American Standard Code for Information Interchange) Ames (Gaines and Hipskind, 1998) format. After the 2-year validation period and internal publication, data were transferred to a public ftp site and to database partners. In 2001 the satellite community asked NDACC to consider the use of the HDF format. The DHF managers have participated in the Generic Earth Observation Metadata Standard (GEOMS) initiative to develop reporting standards for calibration/validation data (De Mazière et al., 2002; https://avdc.gsfc.nasa.gov/index.php?site= 1178067684; last access: 2 April 2018). Today the NDACC DHF is based on dual Linux servers with dynamic failover and houses data from 148 active instruments at 80 sites, as well as campaign data and data from past instruments. These data are publicly available at ftp://ftp.cpc.ncep.noaa. gov/ndacc/station (last access: 2 April 2018). The NDACC 


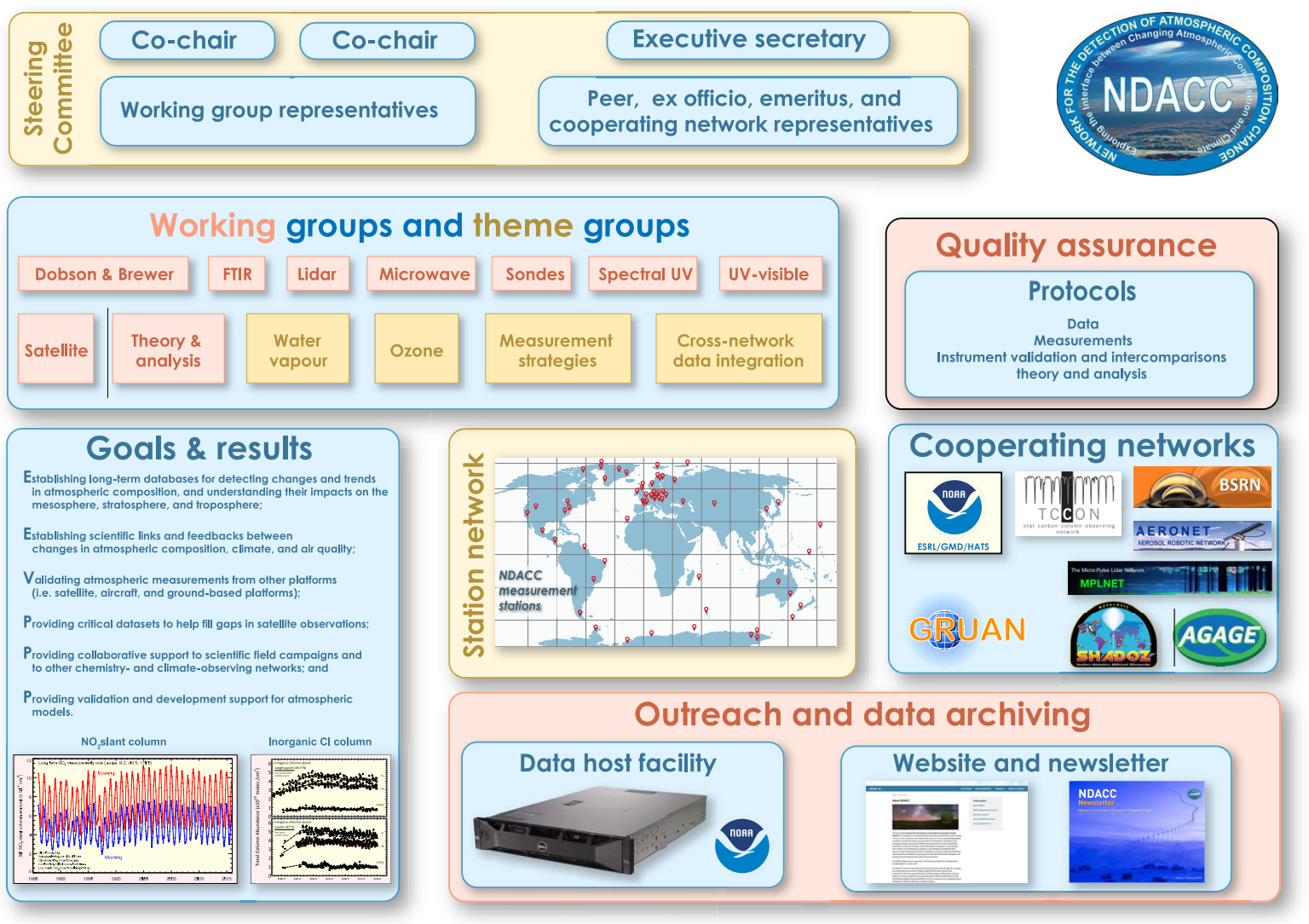

Figure 3. Organizational structure of NDACC and the logo. More details of Steering Committee and working and theme group composition, documents related to group activities, along with the data, are found at the website http://www.ndacc.org (last access: 2 April 2018).

Table 2. List of cooperating networks.

\begin{tabular}{ll}
\hline Cooperating network & Website \\
\hline AErosol RObotic NETwork (AERONET) - 2009 & http://aeronet.gsfc.nasa.gov (last access: 2 April 2018) \\
Advanced Global Atmospheric Gases Experiment (AGAGE) - 2009 & http://agage.eas.gatech.edu/index.htm (last access: 2 April 2018) \\
The Baseline Surface Radiation Network (BSRN) - 2011 & http://www.bsrn.awi.de (last access: 2 April 2018) \\
GCOS Reference Upper-Air Network (GRUAN) - 2013 & http://www.gruan.org (last access: 2 April 2018) \\
The Halocarbons and other Trace Species (HATS) - 2009 & http://www.esrl.noaa.gov/gmd/hats (last access: 2 April 2018) \\
The NASA Micro Pulse Lidar Network (MPLNET) - 2009 & http://mplnet.gsfc.nasa.gov (last access: 2 April 2018) \\
Southern Hemisphere Additional Ozonesondes (SHADOZ) - 2009 & http://tropo.gsfc.nasa.gov/shadoz (last access: 2 April 2018) \\
Total Carbon Column Observing Network (TCCON) - 2011 & http://www.tccon.caltech.edu (last access: 2 April 2018) \\
\hline
\end{tabular}

DHF engages in collaboration with AVDC (Aura Validation Data Center), GAWSIS (Global Atmosphere Watch Station Information System), GECA (Generic Environment for Calibration/validation Analysis; Meijer et al., 2009), and WOUDC (World Ozone and Ultraviolet Radiation Data Centre; http://woudc.org/; last access: 2 April 2018), where the NDACC database can be searched remotely; in some cases additional visualization tools are provided.

In an effort to provide a clearer and more direct path to access NDACC data, the NDACC web page has been redesigned. Data search tools include dynamic search by maps, instrument type, and station listing. The content management system (CMS)-based design provides simple tools for updating documentation and enforcing documentation requirements resulting in information that is more visible and more easily accessed than in the past. Figure 4 shows the newly designed website which is available at www.ndacc.org (last access: 2 April 2018). 


\section{$\begin{array}{lll}\text { NDACC } & \text { STATIONS INSTRUMENTS SEARCH ABOUT NDACC }\end{array}$}

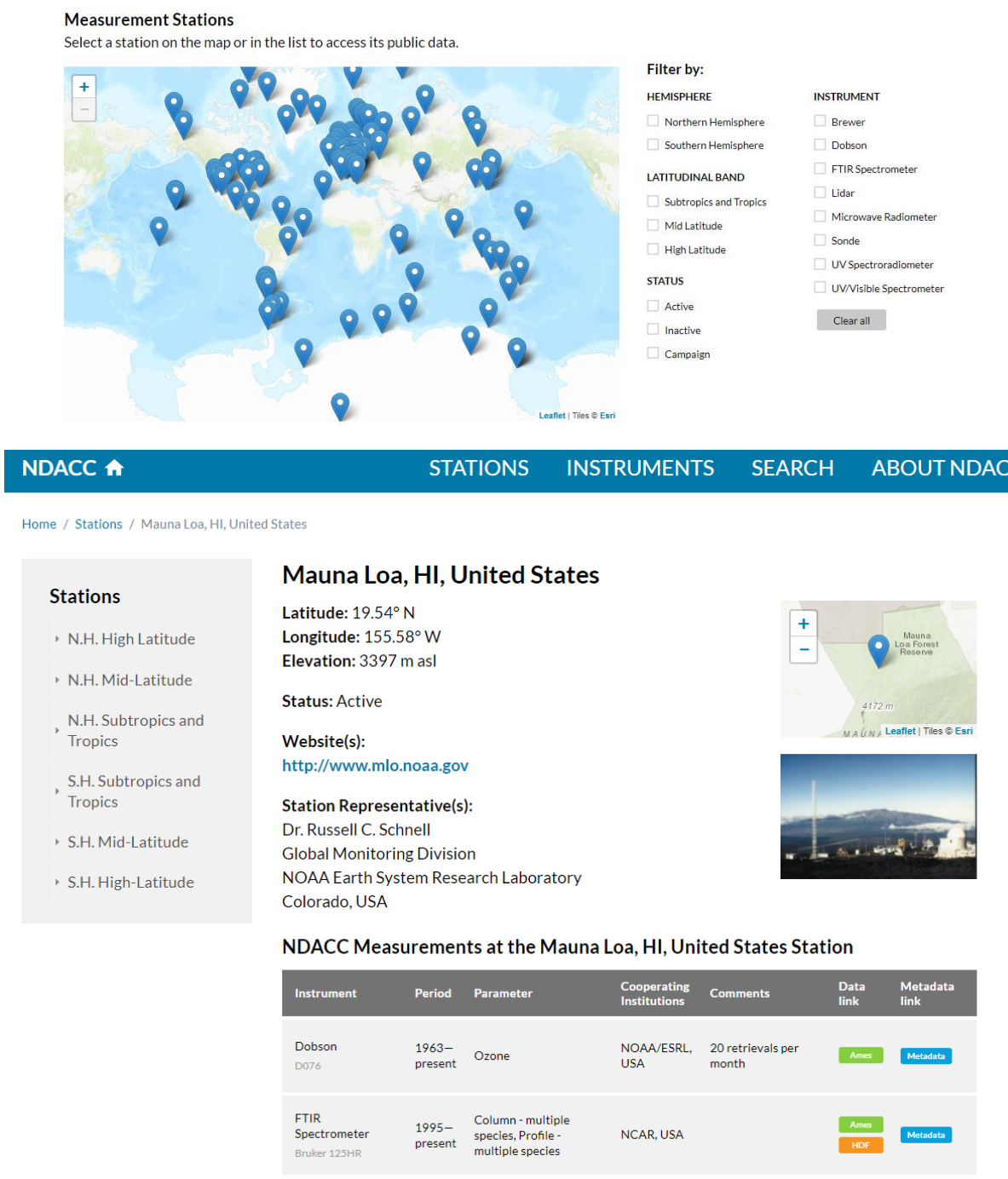

Figure 4. The newly redesigned NDACC website at www.ndacc.org (last access: 2 April 2018). (a) Stations are searchable by a dynamic map with filters. (b) Station pages allow direct access to data and metadata instrument description files.

\section{Important NDACC achievements during 25 years of monitoring atmospheric composition change}

The following contributions of NDACC demonstrate the centrality of its measurements program and the invaluable roles played by consistent, standardized, long-term measurements that are organized in a network. These examples also illustrate how NDACC is integrated into other atmospheric activities like SPARC (Stratosphere-troposphere Processes and their Role in Climate), GCOS (Global Climate Observing System), IGACO (Integrated Global Atmospheric Chemistry Observations, the $\mathrm{IO}_{3} \mathrm{C}$, CAMS (Copernicus Atmosphere Monitoring Service), C3S (Copernicus Climate Change Service), and the WMO/Global Atmosphere Watch (GAW).
The most recent achievements are reported in the scientific papers in this special issue and listed and categorized in Appendix A, or they are referenced in the below sections.

\subsection{Long-term ozone monitoring}

Figure 5 shows the blending of upper-stratospheric ozone time series from satellite data (SAGE (Stratospheric Aerosol and Gas Experiment), OSIRIS (Optical Spectrograph and InfraRed Imager System), ESA-CCI (Climate Change Initiative; http://cci.esa.int/; last access: 2 April 2018), SWOOSH (The Stratospheric Water and OzOne Satellite Homogenized; https://www.esrl.noaa.gov/csd/groups/csd8/swoosh/; last access: 2 April 2018) and GOZCARDS (Global OZone Chemistry And Related trace gas Data records for the Strato- 


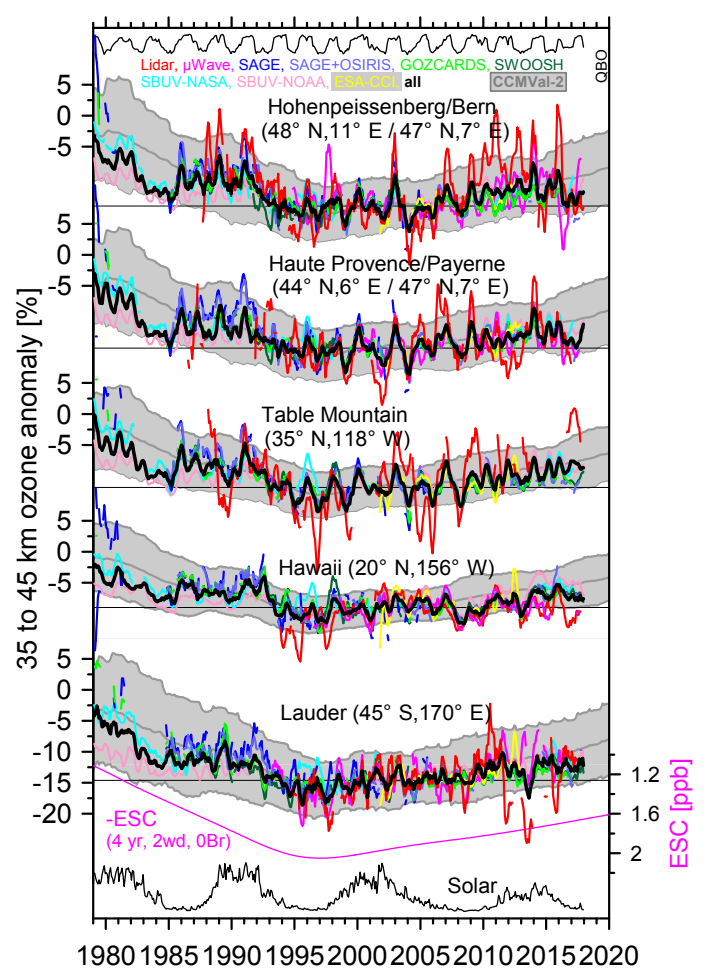

Figure 5. The essential synergism of NDACC measurements with data from satellites. The grey area shows the range of model simulations from the CCMVal-2 initiative. Also shown at the top and bottom are sources of expected natural variability (QBO and solar cycle, respectively) and the evolution of man-made ESC (effective stratospheric chlorine, magenta line; note the reversed scale on the right). The data are used for verifying the success of the Montreal Protocol.

sphere; https://gozcards.jpl.nasa.gov/info.php; last access: 2 April 2018)) merged data sets, SBUV-MOD (Solar Backscatter Ultraviolet Instrument Merged Ozone Data set) with reference data sets from more than 2 decades of measurements by NDACC lidars and microwave radiometers. Note that the quasi-biennial oscillation (QBO) and the solar cycle, indicators of natural phenomena that affect stratospheric ozone amounts, are also shown (thin black lines). Ground-based microwave instruments provide continuous measurements of ozone and can thus provide information on diurnal variations in ozone (Haefele et al., 2008; Parrish et al., 2014). This is of particular value for interpreting satellite measurements, which drift in local time.

The response of stratospheric ozone, first to the increasing atmospheric abundance of ozone-depleting substances (ODS; represented by ESC (effective stratospheric chlorine) in the lower part of Fig. 5, magenta line; note the inverse scale on the right) and then to their decline, is clearly visible. The decline in ESC after 1997 is a direct result of the Montreal Protocol (1987) and its Amendments and Adjustments. The success of this international protocol stopped or reversed the previous decline in ozone seen at all sites until approximately 2000. Since then, the onset of ozone increases becomes apparent, especially at the midlatitude stations. Complete ozone recovery (i.e. to 1980 benchmark levels) from the effects of halogen catalysed destruction is projected to occur by the mid-21st century at midlatitudes and over the Arctic and somewhat later for the Antarctic ozone hole. However, as chemistry climate model simulations show (e.g. from CCMVal-2 (Chemistry-Climate Model Validation activity 2); grey-shaded range in Fig. 5), increases in greenhouse gas abundances over this same period are expected to enhance this stratospheric ozone recovery.

\subsection{Constraining uncertainties in ozone absorption cross sections}

NDACC instrument scientists have been important participants in the Absorption Cross Sections of Ozone (ACSO) activity conducted as a joint initiative of the $\mathrm{IO}_{3} \mathrm{C}$, the WMO, and the IGACO $\mathrm{O}_{3} / \mathrm{UV}$ subgroup to study, evaluate, and recommend the most suitable ozone absorption cross section laboratory data to be used in atmospheric ozone measurements. Comparisons of NDACC ozone products generated by various different instrument types helped determine the range of uncertainty associated with the stratospheric temperature dependence of the instrument-specific absorption cross sections that are operationally used in derivation of these data products. These determinations led to ACSO recommendations for using various spectroscopic data published in the literature and to conduct further laboratory measurements (http://www.wmo.int/pages/prog/arep/ gaw/documents/FINAL_GAW_218.pdf; last access: 2 April 2018).

This activity supports the data analysis from the Dobson and Brewer networks in NDACC. In 2016, the $\mathrm{IO}_{3} \mathrm{C}$ recommended replacing the Bass and Paur (1985) ozone cross sections with those of Gorshelev et al. (2014) and Serdyuchenko et al. (2014), partly because the use of the latter improved total ozone agreement between Dobson and Brewer instruments (Redondas et al., 2014). Koukouli et al. (2016) showed, in addition, the importance of correcting effective temperature errors in the Dobson spectrophotometers. Note that updates of Dobson data have been ongoing. NOAA coordinates the data collection for 14 of these instruments, with 7 of them (Mauna Loa, Boulder, Lauder, OHP, American Samoa, Wallops, South Pole) reporting to NDACC. A recent software update resulted in a re-evaluation of the Dobson ozone record for the NOAA instrument complement. The new records were compared to the original NDACC and WOUDC records (Evans et al., 2017). At the completion of the evaluation, new data sets were archived at NDACC and WOUDC. Another large reprocessing effort that will update the NDACC Dobson and Brewer records with new absorption cross sections is underway. 


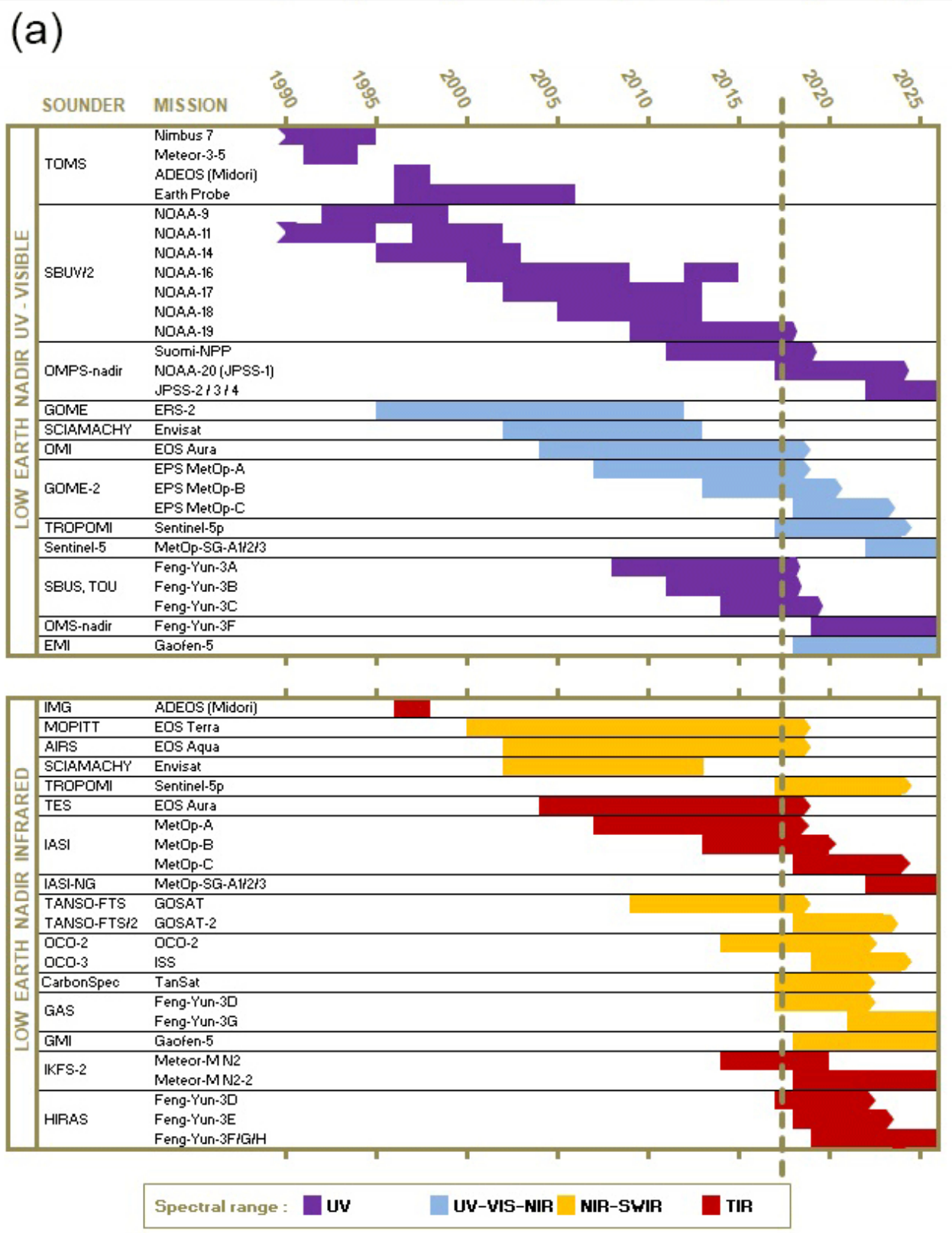

Figure 6.

\subsection{Reference measurements for satellite validation}

In the 1980s a few ozone monitoring stations - mainly equipped with Dobsons, Brewers, DOAS UV-visible spectrometers, lidars, and ozone-sondes - had already been used as ground-based references for the geophysical validation of TOMS (Total Ozone Mapping Spectrometer) column and SAGE-II and SBUV/2 profile data. With the advent of newgeneration satellite measurements in the 1990s (e.g. UARS, ATLAS, Global Ozone Monitoring Experiment (GOME), ADEOS (Advanced Earth Observing Satellite), EOS (Earth Observing System )-Terra) and 2000s (Odin, Envisat (Envi- ronmental Satellite), SCISAT(Canadian Space Agency's Science Satellite)-1 ACE (Atmospheric Chemistry Experiment), EOS-Aura, MetOp (Meteorological Operational Satellite), GOSAT (Greenhouse Gases Observing Satellite)), these pioneering validation activities have progressively developed to encompass all types of NDACC instruments and their complete portfolio of species and parameters. Validations based on single instruments at single stations have expanded to more comprehensive assessments using the network as a whole (e.g. Lambert et al., 1999). The portfolio of NDACC data products has gradually been enhanced to meet emerging needs of the satellite community. To date, NDACC has 


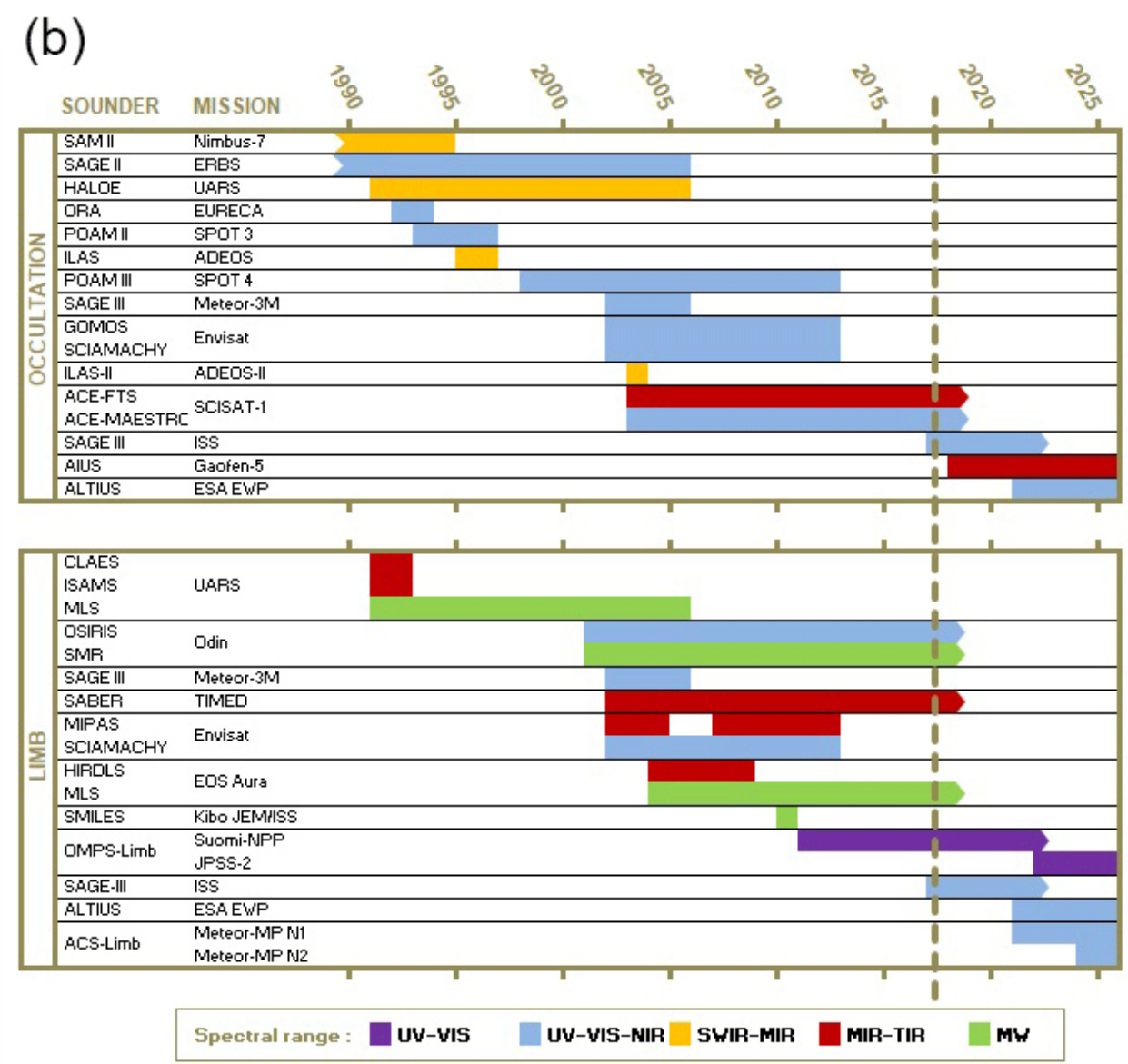

Figure 6. (a) Low earth orbit nadir-viewing satellite sounders supported by NDACC, from the inception of the NDSC through to the present day and beyond. Upper chart: backscatter UV $\left(\mathrm{O}_{3}\right)$ and UV/VIS $\left(\mathrm{O}_{3}, \mathrm{NO}_{2}, \mathrm{BrO}, \mathrm{HCHO}\right.$, etc.) Lower chart: backscatter NIR/SWIR (nearinfrared/shortwave infrared) (typically $\mathrm{CH}_{4}, \mathrm{CO}, \mathrm{H}_{2} \mathrm{O}, \mathrm{N}_{2} \mathrm{O}$ ) and MIR/TIR (middle infrared/thermal infrared) emission $\left(\mathrm{O}_{3}, \mathrm{CH}_{4}, \mathrm{CO}_{2} \mathrm{~N}_{2} \mathrm{O}\right.$, $\mathrm{H}_{2} \mathrm{O}, \mathrm{HNO}_{3}, \mathrm{HCl}, \mathrm{CFC}-11, \mathrm{CFC}-12$, etc.). (b) Low earth orbit limb-viewing satellite profilers supported by NDACC, from the inception of the NDSC through present day and beyond. Upper chart: solar (and stellar) occultation instruments measuring in the UV/VIS/NIR (typically $\mathrm{O}_{3}, \mathrm{NO}_{2}, \mathrm{BrO}, \mathrm{H}_{2} \mathrm{O}$, aerosols, etc.) and the MIR/TIR (typically $\mathrm{O}_{3}, \mathrm{NO}, \mathrm{NO}_{2}, \mathrm{HNO}_{3}, \mathrm{CH}_{4}, \mathrm{CO}, \mathrm{H}_{2} \mathrm{O}, \mathrm{CFC}-11, \mathrm{CFC}-12$, aerosols, etc.). Lower chart: limb-scanning instruments measuring scattered light solar radiation (typically $\mathrm{O}_{3}, \mathrm{NO}_{2}, \mathrm{H}_{2} \mathrm{O}$, aerosols, etc.), MIR/TIR emission (typically $\mathrm{O}_{3}, \mathrm{NO}, \mathrm{NO}_{2}, \mathrm{HNO}_{3}, \mathrm{~N}_{2} \mathrm{O}, \mathrm{CH}_{4}, \mathrm{CO}, \mathrm{H}_{2} \mathrm{O}, \mathrm{HCl}, \mathrm{ClONO}_{2}, \mathrm{CFC}-11, \mathrm{CFC}-12$, aerosols, etc.), and $\mathrm{MW}$ emission (typically $\mathrm{O}_{3}$, $\mathrm{HCl}, \mathrm{ClO}, \mathrm{N}_{2} \mathrm{O}, \mathrm{H}_{2} \mathrm{O}, \mathrm{HNO}_{3}$, etc.).

contributed sustained support to the geophysical validation and algorithm evolution of over 50 space-based sounders. These include the series of nadir-viewing UV-visible and infrared sounders and the limb and occultation profilers on the UARS, Odin, Envisat, SCISAT-1 and EOS-Aura platforms (Fig. 6a and b). NDACC data have also been used to assess the stability and mutual consistency of multiple satellite data records across a multi-decadal period, e.g. McPeters and Labow (1996); McPeters et al. (2008); Fioletov et al. (2008); Antón et al. (2009); Flynn et al. (2014); Bak et al. (2015); Koukouli et al. (2015); Hubert et al. (2016). NDACC is also supporting current operational missions like MetOp, Suomi-NPP (Suomi National Polar-orbiting Partnership), SAGE III/ISS (International Space Station), Sentinel- 5p TROPOMI (TROPOspheric Monitoring Instrument), and JPSS (Joint Polar Satellite System)-1 and is recognized as a key source of Fiducial Reference Measurements (FRMs) for the validation of the upcoming Copernicus atmospheric Sentinels 4 and 5 and the China High-resolution Earth Observation System (CHEOS).

Given the complete overlap of speciation of the Canadian Space Agency's ACE-FTS (Fourier Transform Spectrometer)/SCISAT and the NDACC FTIR network, the latter provided validation for a suite of gases that were published in a series of papers $\left(\mathrm{O}_{3}\right.$ : Dupuy et al., 2009; $\mathrm{HCl}, \mathrm{HF}, \mathrm{CCl}_{3} \mathrm{~F}$, $\mathrm{CClF}_{2}$ : Mahieu et al., 2008; $\mathrm{NO}_{2}$ and $\mathrm{NO}$ : Kerzenmacher et al., 2008; $\mathrm{N}_{2} \mathrm{O}$ : Strong et al., 2008; $\mathrm{HNO}_{3}, \mathrm{ClONO}_{2}, \mathrm{~N}_{2} \mathrm{O}_{5}$ : Wolff et al., 2008; CO: Clerbaux et al., 2008; $\mathrm{CH}_{4}$ : De Maz- 

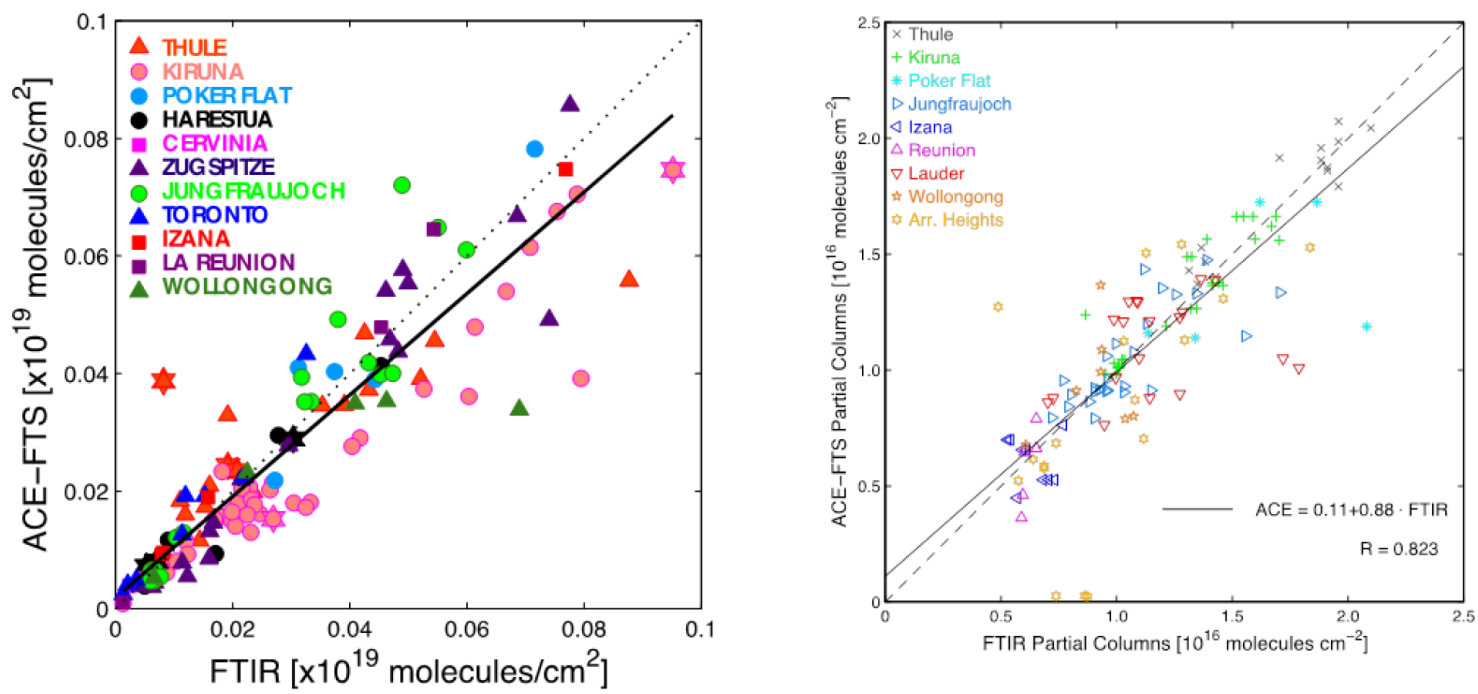

Figure 7. Examples of the validation of new satellite data sets. Panel (a) is reprinted from (Clerbaux et al., 2008) for lower-stratospheric CO measured at $5 \mu \mathrm{m}$ from 11 instruments, 9 of which are located at NDACC stations. The partial column quantities from the ACE-FTS and the FTIR have very similar characteristics in vertical resolution and analysis, providing a precise evaluation of satellite performance. The latitudinal extent of the NDACC sites here from $76^{\circ} \mathrm{N}$ to $34^{\circ} \mathrm{S}$ helps verify the ACE-FTS global coverage. Panel (b) reprinted from (Wolff et al., 2008) shows the correlation of partial columns for HNO3 measured at $10.02 \mu \mathrm{m}$ from nine NDACC stations from $76^{\circ} \mathrm{N}$ to $78^{\circ} \mathrm{S}$.

ière et al., 2008). Figure 7 shows two examples of these satellite validation efforts where the altitude resolution of the FTIR can be isolated to accommodate the satellite sensitivity range. Figure 7a from Clerbaux et al. (2008) compares CO partial columns from $6.5-8.5$ to $20-25 \mathrm{~km}$ depending on station and sensitivity. Figure $7 \mathrm{~b}$ concerns $\mathrm{HNO}_{3}$ partial columns from several stations (Wolff et al., 2008) in the altitude range from $14.6-16.0$ to $29.0-31.0 \mathrm{~km}$.

NDACC lidar and sonde instruments provide insights into the upper troposphere-lower stratosphere (UT/LS), where several satellite measurements are less precise than in the middle and upper stratosphere. The capabilities of lidar and sondes are illustrated in Figs. 8 and 9. In Fig. 8a, a daylong time series of tropospheric ozone lidar variability is shown from the NASA/Goddard Space Flight Center (GSFC) Tropospheric Ozone Lidar (GSFC TROPOZ; Sullivan et al., 2014) alongside six electrochemical concentration cells (ECCs) sondes at the JPL (Jet Propulsion Laboratory) Table Mountain Facility (TMF) during the Southern California Ozone Observation Project (SCOOP). A comparison of the GSFC TROPOZ and JPL-TMF tropospheric lidar is presented in Fig. 8b for the final ECC sounding from Fig. 8a, indicating that both lidars accurately represent the variability and gradients sampled during the sonde ascent in the lower free troposphere as well as in the UT/LS.

In Fig. 9, the longitudinal ozone structure in the TTL (tropical tropopause layer or tropopause transition layer, as the UT/LS is referred to in the tropics) is displayed using the composite tropical Southern Hemisphere Additional Ozonesondes (SHADOZ) data (Thompson et al., 2003, 2012,
2017). The eastern Indian Ocean to Pacific region displays a sharp ozone gradient and high tropopause. The lower ozone values in the latter zone, relative to the South American to African region, in the centre of Fig. 9, are attributed to more active convection in the western Pacific, where relatively unpolluted boundary-layer marine air is rapidly mixed upward. The fine structure of TTL ozone as observed with sondes serves as a reference for satellite retrievals and chemistryclimate models, in a region where ozone and temperature feedbacks are important.

\subsection{Providing precise documentation of the multi-decadal trends of many tropospheric and stratospheric constituents}

High-resolution solar absorption spectra regularly recorded by NDACC FTIR spectrometers under cloud-free conditions provide precise documentation of multi-decadal trends of many tropospheric and stratospheric constituents. For example, extended NDACC FTIR data sets, combined with HALOE (Halogen Occultation Experiment (NASA)) observations from UARS provide evidence of a stabilization of stratospheric chlorine around the mid-1990s (Rinsland et al., 2003). Subsequently, NDACC showed there to be a decrease in atmospheric $\mathrm{HCl}$ and $\mathrm{ClONO}_{2}$ at rates of $\sim 1 \% \mathrm{yr}^{-1}$ in both hemispheres, between $80^{\circ} \mathrm{N}$ and $78^{\circ} \mathrm{S}$ (Kohlhepp et al., 2012). While it is believed that this reversal is due to reduced emissions of anthropogenic source $\mathrm{Cl}$ species and that it will continue, note that the chlorine decline has not been monotonic since 1997 (Fig. 10). More recently, the NDACC FTIR time series provided evidence of a surprising reincrease 

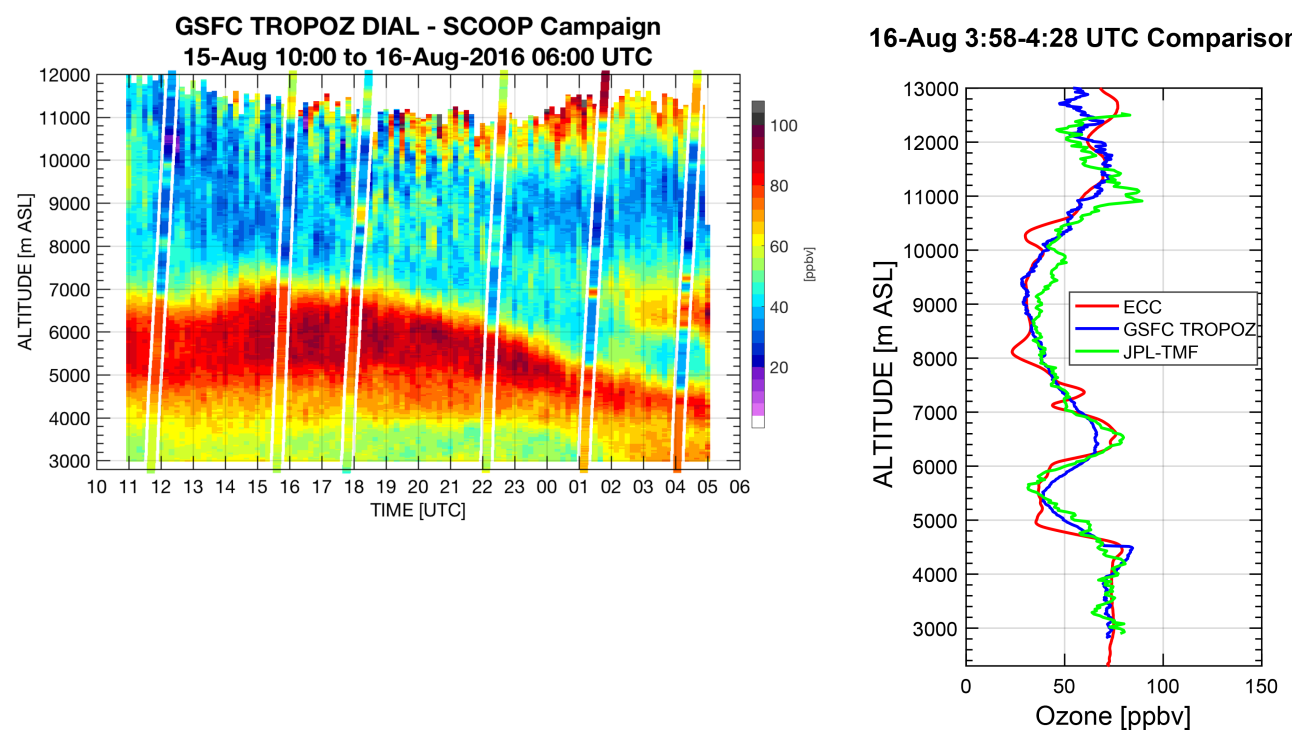

Figure 8. (a) Time series of 10 min GSFC TROPOZ lidar observations during the SCOOP campaign at JPL Table Mountain Facility (site elevation: 2300 m a.s.1.) along with six ECC sondes (denoted by triangles). (b) Comparison of 30 min averaged ozone from GSFC TROPOZ and JPL-TMF ozone lidars as compared to the last sounding of the time series. Courtesy: John T. Sullivan, NASA/GSFC.

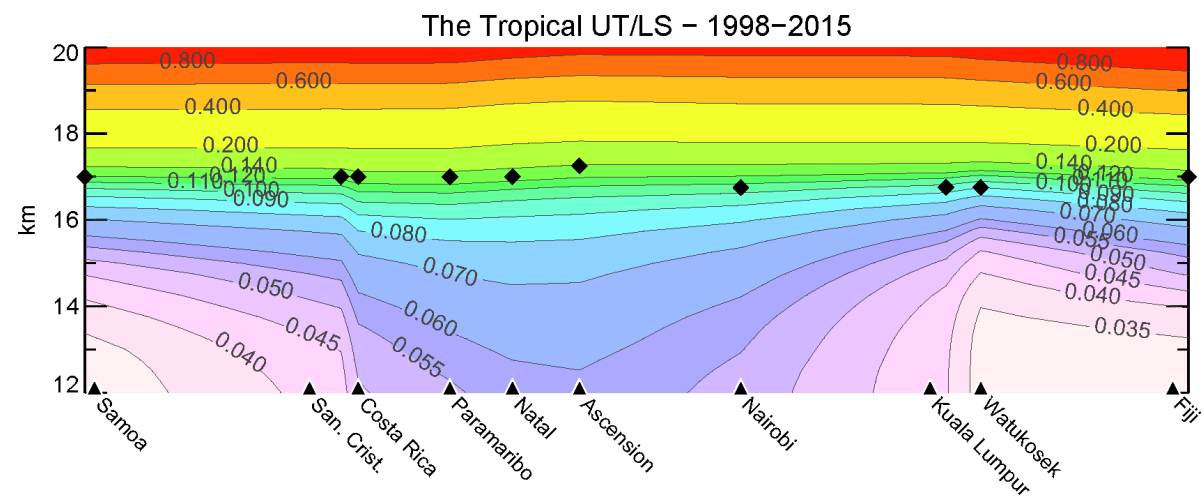

Figure 9. TTL ozone structure (ozone contour lines in ppmv) from SHADOZ from 13-17.5 km above the stations, labelled by their location, equatorward of $19^{\circ} \mathrm{N} / \mathrm{S}$ based on all 1998-2015 data. Courtesy: Jacquelyn C. Witte, NASA/GSFC.

in $\mathrm{HCl}$ in the Northern Hemisphere midlatitude stratosphere of up to $\sim 3 \% \mathrm{yr}^{-1}$ between 2007 and 2011. The cause of the $\mathrm{HCl}$ upturn was identified as being due to changes in atmospheric circulation (Mahieu et al., 2014). This is seen in Fig. 10, which shows the data sets (1983-2016) restricted to the June to November months; this limits the variability caused by atmospheric transport and subsidence mainly during winter-springtime. A good proxy of northern midlatitude total inorganic chlorine $\left(\mathrm{Cl}_{y}\right)$ is obtained by summing the $\mathrm{HCl}$ and $\mathrm{ClONO}_{2}$ total columns (blue triangles). The thin continuous lines correspond to non-parametric least-square fits involving an integration time of about 3 years. Using the 1997.0 Cly column as reference and the bootstrap resampling tool of Gardiner et al. (2008), a mean post-peak rate of change of $-(0.50 \pm 0.15) \% \mathrm{yr}^{-1}$ is obtained for the $1997-$ 2016 time period.
NDACC microwave instruments have also provided evidence for decreasing stratospheric chlorine. Note that measurements of upper-stratospheric $\mathrm{ClO}$ from Mauna Kea, Hawaii, showed a trend of $-0.64 \pm 0.15 \% \mathrm{yr}^{-1}(2 \sigma)$ from 1995 to 2012 (Connor et al., 2013), while microwave measurements of lower-stratospheric $\mathrm{ClO}$ from Scott Base, Antarctica, during the ozone hole season suggest a trend in Cly of $-0.6 \pm 0.4 \% \mathrm{yr}^{-1}$ from 1996 to 2015 (Nedoluha et al., 2016).

NDACC data are also noteworthy for filling gaps in satellite data sets. In Nedoluha et al. (2011), ground-based microwave measurements of upper-stratospheric $\mathrm{ClO}$ were used to show that (within the specified errors) there was no reason to apply any bias correction in order to use UARS MLS (Microwave Limb Sounder) measurements of ClO (1991-1998) and Aura MLS measurements of $\mathrm{ClO}$ (2004-present). 


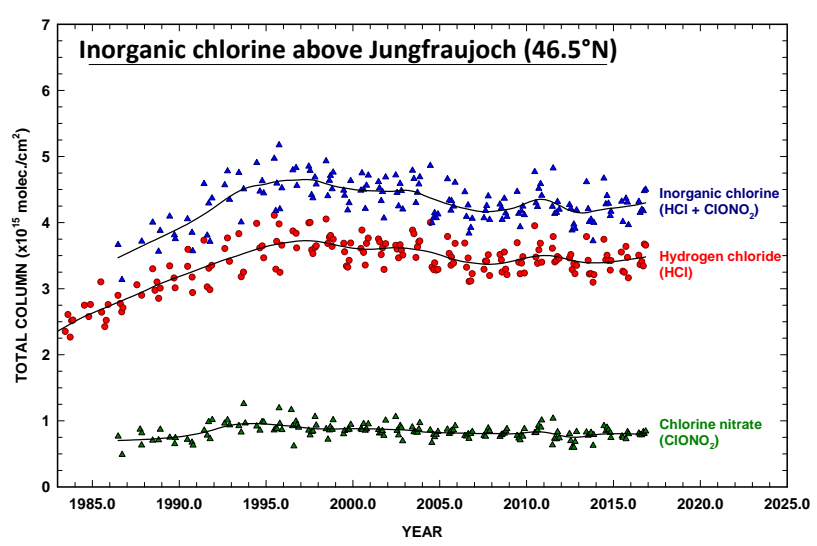

Figure 10. Inorganic chlorine above Jungfraujoch. Multi-decadal monthly mean total column time series of the two main chlorine reservoirs (hydrogen chloride $(\mathrm{HCl}$; red circles) and chlorine nitrate $\left(\mathrm{ClONO}_{2}\right.$; green triangles)), monitored at the Jungfraujoch station (Swiss Alps; $46.5^{\circ} \mathrm{N} ; 3580 \mathrm{~m}$ a.s.1.) in the framework of the NDACC network. The data sets are restricted to the June to November months so as to limit the impact of variability caused by atmospheric transport and subsidence mainly during winter to springtime. A good proxy of northern midlatitude total inorganic chlorine (Cly) is obtained by summing the $\mathrm{HCl}$ and $\mathrm{ClONO}_{2}$ total columns (see blue triangles). The thin continuous lines correspond to non-parametric least-square fits involving an integration time of about 3 years; they help appraise a non-monotonous decrease in chlorine in the stratosphere after 1996-1997. Using the 1997.0 Cly column as reference and the bootstrap resampling tool of Gardiner et al. (2008), a mean post-peak rate of change of $-(0.50 \pm 0.15) \% \mathrm{yr}^{-1}$ is obtained for the 1997-2016 time period. Courtesy: Emmanuel Mahieu et al., Univ. Liège.

The primary halocarbon trace gases, both natural and anthropogenic, that are components of the ESC (Fig. 5) are largely measured through in situ data collection at stations worldwide, mostly from the The Halocarbons and other Trace Species (HATS) and Advanced Global Atmospheric Gases Experiment (AGAGE) cooperating networks (Table 2). The effects of the Montreal Protocol and its follow-on amendments have been clearly observed. The finding that $\mathrm{CCl}_{4}$ (carbon tetrachloride) has not declined in agreement with reported industry production data led to the recent participation of the NDACC and SPARC communities in a targeted assessment of $\mathrm{CCl}_{4}$ (https://www.wcrp-climate.org/ WCRP-publications/2016/SPARC_Report7_2016.pdf; last access: 7 April 2018). Causes for the atmospheric budget disparity include under-reported industrial output, fugitive sources, and unintended manufacture due to numerous secondary reactions of $\mathrm{Cl}$-containing compounds.

In Fig. 11a, a newer application of NDACC FTIR data is shown. There is great interest in whether or not a surge in oil and natural gas (ONG) extraction by unconventional methods (tar sands, hydraulic fracturing, or "fracking") is increasing burdens of non-methane hydrocarbons (NMHCs or volatile organic compounds, VOCs) associated with ONG activity. Increases in ethane column abundances over the period (2003-2015) as measured at five NDACC FTIR sites in Fig. 11 appear together with model interpretation (Franco et al., 2016). Rates of increase vary from $\sim+3 \% \mathrm{yr}^{-1}$ at the remote Mauna Loa station but a little more than $+5 \% \mathrm{yr}^{-1}$ at midlatitude continental locations, Toronto, Boulder, and Jungfraujoch. Franco et al. (2016) have shown that an increase in the North American anthropogenic $\mathrm{C}_{2} \mathrm{H}_{6}$ emissions, dominated by up to $80 \%$ by emissions from the oil and gas sector, from 1.6 in 2008 to $2.8 \mathrm{Tg} \mathrm{yr}^{-1}$ in 2014 , i.e. by $75 \%$, is needed to capture the recent observed rise in $\mathrm{C}_{2} \mathrm{H}_{6}$ atmospheric abundances.

\subsection{Understanding water vapour and assessing the measurement techniques}

Figure 12 displays the change in water vapour over Mauna Loa, Hawaii, as measured by NDACC ground-based microwave measurements near the stratopause since 1996. Nedoluha et al. (2013) showed that, since 2004, these interannual variations tracked closely with both the local variations measured by Aura MLS and those measured from $50^{\circ} \mathrm{S}$ to $50^{\circ} \mathrm{N}$, thus demonstrating the value of single-site measurements of water vapour in this region for understanding near global variations. Together with long-term measurements of water vapour in the lower stratosphere from balloons (e.g. Hurst et al., 2011) the NDACC measurements track the complex long-term changes in stratospheric water vapour. Having a reference for stratospheric water vapour changes from ground-based measurements and balloons will become particularly important in the future when there will be fewer, if any, available satellite measurements of water vapour. Meanwhile, the FTIR long-term data set on the variability in isotopic ratios of water (e.g. Barthlott et al., 2017) has become an important tool for investigating different water cycle processes that are important in Earth's climate system.

\subsection{Latitudinal differences in UV-A and erythemal ("sunburning") radiation}

Latitudinal variations in the annual doses of UV-B (280$315 \mathrm{~nm})$ and UV-A $(315-400 \mathrm{~nm})$ radiation have recently been assessed using data from NDACC UV spectroradiometers (Braathen, 2015; Bais et al., 2015). In Fig. 13, we present an expanded comparison of latitudinal differences between the annual UV-A dose and the annual erythemal dose, i.e. the UV dose on a horizontal surface causing sunburn (McKinlay and Diffey, 1987). Latitudinal gradients are stronger for the erythemal dose than the UV-A dose (Fig. 13a), partly because photons travel a longer path through the atmosphere for the lower solar elevations prevailing at higher latitudes, allowing greater absorption of UV-B radiation by ozone. The ratio of erythemal and UV-A dose (Fig. 13b) is about a factor 


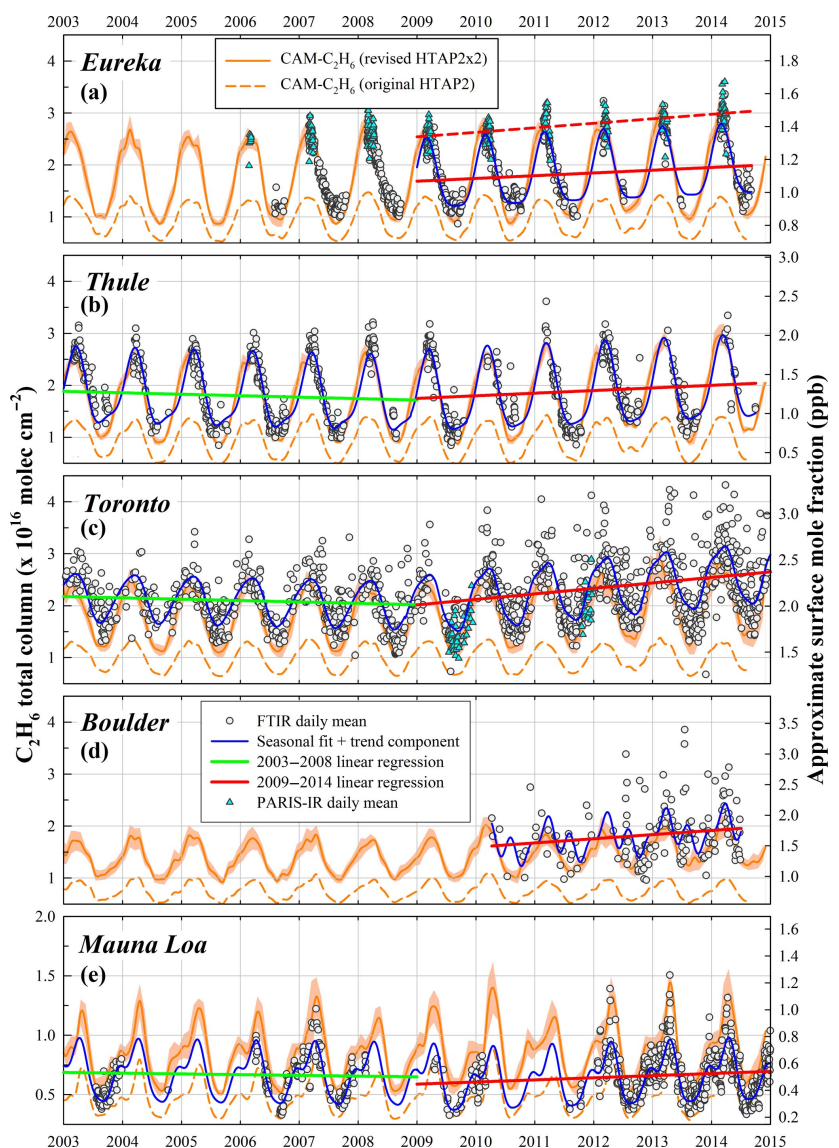

Figure 11. Daily mean $\mathrm{C}_{2} \mathrm{H}_{6}$ total columns derived from the NDACC FTIR (grey circles) and PARIS-IR (Portable Atmospheric Research Interferometric Spectrometer for the infrared; light blue triangles) observations between January 2003 and December 2014. The right $y$ axis scale converts the total columns into approximate surface mole fraction. The blue curve visualizes the function (including seasonal modulation and trend component) fitted to all daily FTIR means over the periods 2003-2008 and 2009-2014, using a bootstrap method. The green and red lines are the associated linear regressions (as a solid line for FTIR and a dashed line for PARIS-IR). The dashed and solid orange curves are the monthly mean $\mathrm{C}_{2} \mathrm{H}_{6}$ total columns simulated by CAM (Community Atmosphere Model)- $\mathrm{C}_{2} \mathrm{H}_{6}$, implementing the original HTAP2 (Hemispheric Transport of Air Pollution experiment 2) and revised HTAP2 inventories, (scaled globally by a factor 2 and since 2008 by $20 \% \mathrm{yr}^{-1}$ in North America), respectively. The shaded area corresponds to the $1 \sigma$ standard deviation.

of 2 larger at the equator than near the poles. This latitudinal dependence is in accordance with earlier findings and similar to that of the ratio of UV-B/UV-A reported by Seckmeyer et al. (2008a) and Bais et al. (2015) because wavelengths in the UV-B range contribute about $90 \%$ to the erythemal dose.

Differences between corresponding latitudes in the Northern Hemisphere and the Southern Hemisphere can be attributed to differences in cloudiness, total ozone, aerosol loading, Sun-Earth separation, altitude, and albedo (Seck-

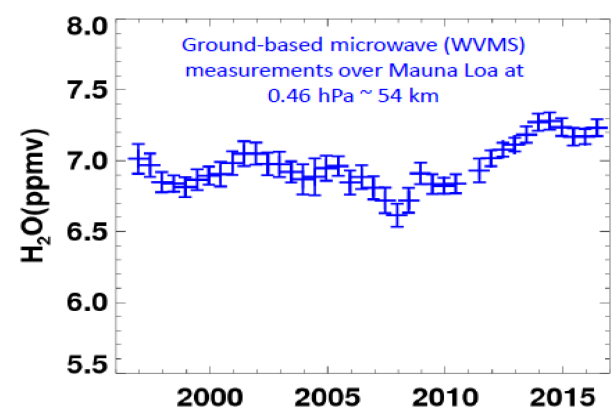

Figure 12. Annual average water vapour mixing ratios at $54 \mathrm{~km}$ $(\sim 0.46 \mathrm{hPa})$ over Mauna Loa $\left(19.5^{\circ} \mathrm{N}, 204.4^{\circ} \mathrm{E}\right)$. Symbols are shown for January-December and July-June; the seasonal cycle has been removed. Thus, each measurement is included in two annual anomalies. Mixing ratios are retrieved from $\sim$ weekly integrated spectra; error bars represent the standard deviation of the mean relative to a seasonal climatology.

meyer et al., 2008b; Bais et al., 2015). The annual erythemal dose is approximately a factor of 4 larger in the tropics than at high latitudes. In the tropics, it reaches about $1.75 \mathrm{MJ} \mathrm{m}^{-2}$ near sea level. This corresponds to an average daily dose of $4800 \mathrm{~J} \mathrm{~m}^{-2}$ (or 48 standard erythemal doses; SEDs). For fair skinned individuals (skin type I), the minimal dose leading to reddening of the skin is about $200 \mathrm{~J} \mathrm{~m}^{-2}$ (Vanicek et al., 2000). Hence, the average daily dose at the equator is about 24 times the minimal erythemal dose (MED). Note that the maximum daily erythemal dose ever observed at Mauna Loa is $9500 \mathrm{~J} \mathrm{~m}^{-2}$ (or $95 \mathrm{SED}$; McKenzie, 2017).

In Antarctica, the prevailing low solar elevations are partly compensated for by high surface albedo, $24 \mathrm{~h}$ of sunlight in the summer, the effect of the ozone hole, and high surface elevation (Bernhard et al., 2010). Because of these factors, annual erythemal UV doses in Antarctica are still significant and within a factor of 2 of midlatitude values. Figure 13a also indicates that high-altitude stations (South Pole, Mauna Loa, Boulder, Hoher Sonnblick, and Summit) receive considerably higher erythemal and UV-A doses than stations closer to sea level (for example, compare Hoher Sonnblick to GroßEnzersdorf and Barrow to Summit). High surface reflectivity ranging from 0.96 to 1.00 also contributes to the relatively large doses at the South Pole and Summit (Bernhard et al., 2008), whereas the attenuation of UV radiation by clouds and aerosols is responsible for the relatively low dose at Tokyo (McKenzie et al., 2008).

NDACC spectral UV measurements have also been used recently to validate surface UV levels derived from satellite observations, specifically from the Ozone Monitoring Instrument (OMI) on Aura and the GOME-2 instrument on MetOp-A (Brogniez et al., 2016). 


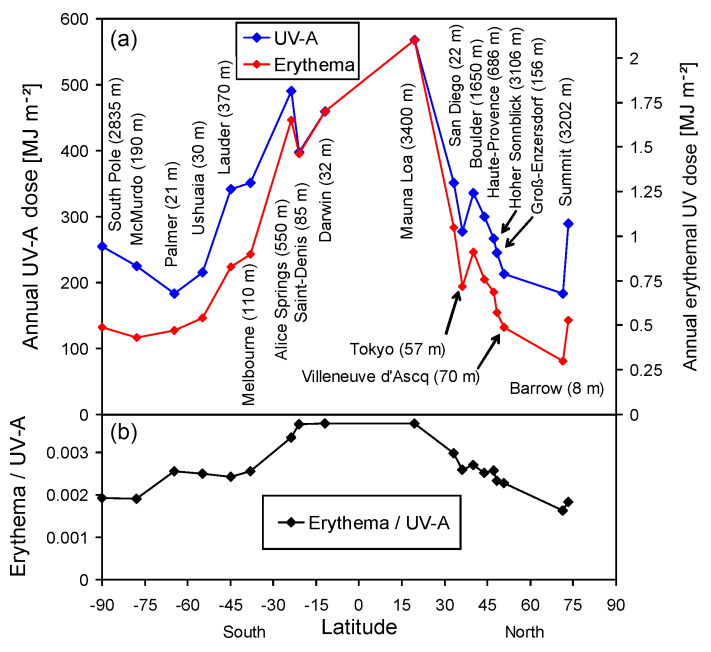

Figure 13. Latitudinal variation of UV-A and erythemal annual dose (a) on a horizontal surface and (b) the ratio of erythemal/UVA dose. Note that high-altitude stations (South Pole, Mauna Loa, Boulder, Hoher Sonnblick, Summit) receive considerably higher erythemal and UV-A doses than stations closer to sea level (Groß-Enzersdorf, Barrow). Instruments at Melbourne, Darwin, San Diego, and Tokyo are not formally part of NDACC but use the same instrumentation and data processing methods as NDACCaffiliated stations.

\subsection{Evaluating coupled chemistry-climate models}

NDACC data have been used in the evaluation of coupled chemistry-climate models (CCMs) under the CCMVal activity conducted by the SPARC project of the World Climate Research Program (WCRP) in which the radiative, dynamical, transport, and chemical processes in the models were analysed in unprecedented detail. In particular, the long time series of NDACC column observations of $\mathrm{HCl}$ and $\mathrm{ClONO}_{2}$ from Jungfraujoch $\left(47^{\circ} \mathrm{N}\right)$ were used to evaluate simulated trends in stratospheric chlorine from 1990 to 2007. This comparison revealed unrealistically high and low chlorine levels in some models as well as differences in the simulated partitioning between these species. Douglass et al. (2014) also evaluated the CCMVal models using NDACC data and explained how problems with simulated chlorine impacted predictions of ozone recovery. By using column data from seven NDACC stations spanning $68^{\circ} \mathrm{N}$ to $45^{\circ} \mathrm{S}$, Douglass et al. (2014) determined that simulated total chlorine and the partitioning between $\mathrm{HCl}$ and $\mathrm{ClONO}_{2}$ were controlled by lowerstratospheric transport and thus models with the most realistic transport produced similar ozone projections. This study successfully explained the causal link between poor transport and the wide range of ozone recovery projections of the CCMs.

Model output generated by the Theory and Analysis Working Group are also now available at the website ftp://ftp.cpc. ncep.noaa.gov/ndacc/gmi_model_data (last access: 2 April 2018). Model simulations that are integrated with reanalysis
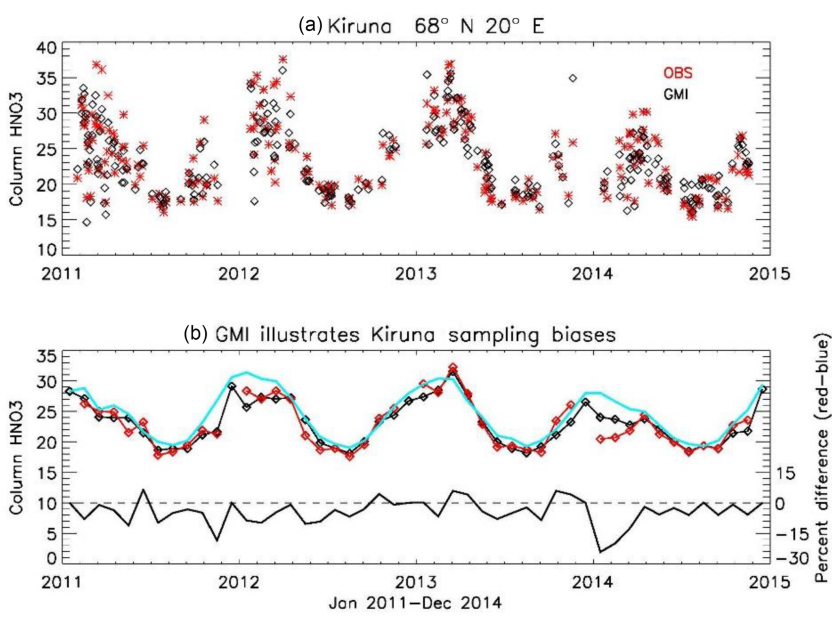

Figure 14. Application of a chemical-transport model (GMI) to interpolation of NDACC data from a polar station (Kiruna; $68^{\circ} \mathrm{N}$, $20^{\circ}$ E). Panel (a) shows 255 FTIR $\mathrm{HNO}_{3}$ measurements. Panel (b) shows how the model with MERRA analyses estimates the impact of sampling bias due to missing winter data.

meteorology have realistic constituent variability from daily to seasonal timescales. Simulated station data are useful for providing an understanding of station data variability and representativeness, thus building a bridge between individual station measurements and the global perspective. Model simulations produced by the group can be used to help set priorities for network expansion and/or instrument relocation.

Figure 14 shows how a simulation with the Global Modeling Initiative (GMI) chemistry transport model integrated with Modern-Era Retrospective analysis for Research and Applications (MERRA) meteorological fields can be used to understand sampling issues at a polar station (Kiruna; $68^{\circ} \mathrm{N}, 20^{\circ} \mathrm{E}$ ). Figure 14a shows $255 \mathrm{FTIR}^{\mathrm{HNO}} 3$ measurements made during a 4-year period. Measurements are sparse in winter when $\mathrm{HNO}_{3}$ columns are highest, leading to bias in calculated seasonal or annual trends. Simulated $\mathrm{HNO}_{3}$ columns from GMI (black) are also shown for Kiruna and only on the same dates as the FTIR measurements. These show realistic seasonal and daily variability, demonstrating the simulation's value for estimating sampling biases. Figure 14b shows simulated $\mathrm{HNO}_{3}$ columns for "monthly" means calculated only from the measurement dates (red), true monthly means (black), and the zonal monthly mean for the $65-70^{\circ} \mathrm{N}$ latitude band (blue). Their differences indicate that the Kiruna FTIR data most closely sample true monthly station means and true monthly zonal means in summer and fall, but in winter, sparse sampling and large dynamical variability in the Arctic lead to large negative biases, especially notable in early 2014 . The mean difference is $-5 \%$. 


\section{NDACC's position in the landscape of atmospheric monitoring networks}

\subsection{Complementarity among existing networks}

As indicated above, NDACC recognizes, on the one hand, the complexity of the atmospheric system and the large variety of needs to appropriately monitor this system and, on the other hand, the existence of a multitude of atmospheric monitoring networks, each of which have a particular focus and level of maturity. NDACC fills a particular niche in this landscape, with its focus on the long-term monitoring of the atmospheric composition (gases and particles) from the free troposphere to the lower mesosphere with dynamics (temperature and winds) for addressing the objectives outlined in Sect. 1.1. It essentially uses six ground-based remote-sensing techniques and sonde measurements, complemented by theoretical and modelling activities and satellite observations. NDACC further complements the cooperating long-term monitoring networks of in situ atmospheric composition like AGAGE and HATS (see Table 2). By contributing stratospheric aerosol measurement, NDACC augments EARLINET (European Lidar Network) and MPLNET that have their focus on tropospheric aerosol.

NDACC and its cooperating networks make synergistic use of data from all the networks, thus benefitting from each other's expertise in addressing scientific questions and identifying common issues, e.g. spectroscopic requirements, the need for infrastructure for digital services in terms of networking, computing and data management, and reporting guidelines.

\subsection{Tiered system of systems}

Thorne et al. (2017) have considered the landscape of existing networks as a tiered system of systems. In this system, the networks are categorized as reference, baseline, or comprehensive, depending on a number of maturity criteria for the observations, for the reported data, their availability and characterization, and for the usage of the data and the sustainability of the network. The scoring for the different maturity criteria is represented in a maturity matrix.

The application of these maturity criteria to NDACC shows that NDACC satisfies the requirements of a reference network at several sites and for several types of instruments, which means that at these sites and for these instruments it provides well-documented, meteorologically traceable observations, with quantified uncertainties, which are easily accessible (Thorne et al., 2017).

Because of its high, close to reference, quality, NDACC is among the networks that are recognized by the European Copernicus initiative as key for providing data for the validation of the CAMS (https://atmosphere.copernicus.eu/ user-support/validation/verification-global-services; last access: 2 April 2018) products and for providing ground- based data in the Copernicus Climate Change Service (C3S_311A_LOT3 contract: Access to Observations from Baseline and Reference Networks). Similarly, it is among the key networks providing FRMs for satellite systems, including the provision of independent data for the validation of satellite climate data records for ozone in the ESA Climate Change Initiative (CCI; http://www.esa-ozone-cci.org/; last access: 2 April 2018)

Work is continuously ongoing to improve the reference quality of NDACC data; this work is supported in part by ESA in its FRM programme, e.g. for the UV-visible DOAStype measurements.

\section{Recent evolution of NDACC and challenges}

\subsection{Measurement strategies}

\subsubsection{Quality assurance}

Since its operational start in 1991, NDACC has paid great attention to ensuring the quality of the individual data as well as the consistency of the data throughout the network. The expansion of the network, as well as the scientific questions that the community is addressing (e.g. the need for precise ozone trend estimates, the use of NDACC data for satellite validation), have intensified the quality requirements. Several working groups have established strategies to better ensure station consistency in operations (e.g. Peters et al., 2017) to deal with uncertainty estimations (e.g. Leblanc et al., 2016ac) and to better document data through reporting guidelines and traceability requirements. The transition from the NASA Ames format to the GEOMS HDF format for data reporting and archiving (see Sect. 2.3) supports efforts for better documentation and traceability. Additional efforts are underway, with support from the European Union in the Copernicus framework, to improve the quality and consistency of the data reporting in the GEOMS HDF format, which will result in an enhanced accessibility and quality of the NDACC DHF. Also, a tool to enable the user to convert the data from GEOMS HDF to NetCDF will be made available on the NDACC DHF.

Network quality control and site-to-site consistency have been achieved through different methods. Intercomparison campaigns were a primary method. These usually gather many instruments, e.g. UV-visible spectrometers in the Cabauw campaigns in a single location (Piters et al., 2012). In the case of the Infrared Working Group (IRWG), side-byside deployment of several instruments including a mobile FTIR instrument was made to compare instruments and to harmonize operating procedures (e.g. Goldman et al., 1999). Mobile reference instruments are used for cross-calibrating stratospheric lidar (Godin et al., 1999; Keckhut et al., 2004; Steinbrecht et al., 2009) and to maintain rigorous standards within the Dobson network (Komhyr et al., 1989; Evans et 
al., 2017). For ozone-sondes the World Centre for Calibration of Ozonesondes in Jülich operates a chamber in which several instruments are tested simultaneously with ozone, temperature and pressure profiles that simulate environments from tropical to polar conditions (Smit et al., 2007, 2014). These intercomparisons typically include a blind analysis phase when one or more outside referees review the data ahead of the instrument investigator team. At times intercomparisons become inefficient or impractical. In that case, for spectrometric methods, quality checks can be based more heavily on cell measurements (Hase, 2012) and continued retrieval intercomparisons. Quality checks using $\mathrm{XCO}_{2}$ retrievals have been suggested by Barthlott et al. (2015), where a correlation among several FTIR sites shows a very good site-by-site consistency. In addition, NDACC has offered a framework for the evaluation of retrieval algorithms, e.g. the work by Leblanc et al. (1998) in examining and comparing lidar temperature retrieval algorithms using simulated data, and subsequent work standardizing resolution and error budgets in temperature, ozone, and water vapour measurements with lidar (Leblanc et al., 2016a-c).

Several NDACC instrument working groups are considering centralized data processing in order to avoid inconsistencies among the individual stations/partners that originate in differences in data processing software. In some instrument working groups, like the Infrared Working Group, standard data processing software is already used by all partners, but this does not completely avoid discrepancies due to software being implemented in a different way or used with different parameters/settings. Transitioning to standard data processing software or centralized data processing is challenging because NDACC has been and remains a research-oriented network, in which some instruments have been uniquely developed by the PI with customized data processing codes. This is especially the case when the PIs play essential roles in the reporting of the data and have worked to ensure their data quality, uncertainties, and network consistency through data intercomparison campaigns (e.g. Deshler et al., 2008, 2017; Piters et al., 2012; Kreher et al., 2018; Sterling et al., 2017; Thompson et al., 2017; Witte et al., 2017). Nevertheless, in cases where there is a need for a more operational data delivery, e.g. for satellite and model validation purposes, efforts are underway to set up prototype centralized processing systems, e.g. in the UV-visible Working Group with support from ESA. These quality assurance efforts can be important in elevating the maturity level of NDACC.

\subsubsection{Rapid data delivery}

NDACC instrument PIs have always been encouraged to deliver data as soon as possible. Recently, in the spirit of more operational data delivery, the time frame for offering NDACC data to the public has been shortened from 2 years to 1 year after acquisition. Additionally, a separate section has been created in the data archive, called the Rapid Delivery
(RD) database (ftp://ftp.cpc.ncep.noaa.gov/ndacc/RD/; last access: 2 April 2018), where data users can find preliminary NDACC data and data from candidate stations; these data have not yet been completely quality-controlled but are sufficiently reliable for supporting at least preliminary satellite or model validation.

\subsection{Challenges}

\subsubsection{Continuity of measurements}

The maintenance of trend-quality stable measurements over the past 25 years, often under inhospitable environmental conditions, and the operation of such instruments over future decadal timescales, is, and will continue to be, a daunting challenge. Stable measurements require that aging instrumental components be replaced on a regular basis, and, as technologies become obsolete, upgraded components must be deployed. Upgrading instruments can both improve measurement quality and allow for continued operation under tight fiscal constraints. Making such transitions while providing the community with stable data sets will continue to require careful engineering, intercomparisons, and measurement evaluation.

In addition to the scientific and engineering challenges of long-term measurements, there are fiscal challenges of maintaining such support in an ever changing budget environment. Even a brief gap in funding imperils the continuity that is crucial for determining long-term trends, which is the fundamental goal of NDACC. Changing scientific priorities may shift away from long-term ground-based measurement programmes, often towards space-borne platforms. In the latter case, space agencies may not recognize their strong dependence on NDACC-type data for validation and assume that other scientific sponsors will provide the necessary long-term financial support.

\subsubsection{Role in scientific assessments}

The standard complement of NDACC instruments/sites should be considered as an essential part of a research infrastructure that delivers high-quality data for atmospheric parameters, trace gases, and aerosols to the scientific community and to the policy makers for a multitude of purposes. These infrastructures, including instrument maintenance (upgrading, cross-calibration, etc.) and the data they deliver, deserve continuous support from the stakeholders to ensure the fulfillment of the research and to provide the essential scientific basis for environmental policies. For example, the current threats associated with climate change require continuous, long-term high-quality monitoring and reporting of the state of the atmosphere, including its chemical composition, analogous to the obligations that many nations have assumed for air quality monitoring and reporting. 
Indeed, an important lesson learnt from NDACC is the necessity of having multiple and independent long-term records. The high level of accuracy and stability needed to observe small and slow changes in the atmosphere rests on comparing a number of different instruments and techniques. Only with such data can the community support the Intergovernmental Panel on Climate Change in assessing the current state of the Earth's climate and for ensuring that mitigation and adaptation options are rooted in high-quality observations. The same holds true for the WMO/UNEP Scientific Assessments of Ozone Depletion: e.g. the lack of plans to fly limb satellite sounders operationally highlights the urgent need to maintain a strong ground-based measurement system so as to be able to support the WMO in its task to assess the state of the ozone layer every 4 years as requested by the Montreal Protocol.

\section{Concluding perspectives}

NDACC is transitioning to a network that is both researchoriented and operationally oriented, providing data and analyses to a large variety of users: researchers, large-scale initiatives like Copernicus, space agencies of many countries, policy-oriented assessments, and the public at large. These data users rely on NDACC remaining healthy, with a wellsupported infrastructure and with a dedicated operational infrastructure (i.e. the community of scientific experts) that updates measurement capabilities to meet new data needs.

However, this evolution must not hinder further development of the network for pure research purposes, which in the longer term will also serve the other users.

Some of the future developments envisaged in NDACC include

1. filling important gaps in the network spatial and temporal coverage, i.e. there are currently few stations in the tropics, notably in South America, Asia, and Africa. Few observations cover the full diurnal cycle; this will be essential for the validation of geostationary satellites. Model-based network design will help to identify where such coverage (spatial and temporal) gaps lie.

2. filling important gaps in the ensemble of atmospheric variables that are observed (e.g. as new ODS-substitute products are released by human activities, it is important to monitor their fate and their evolution in the atmosphere).

3. refining existing and/or developing new measurement techniques to improve the accuracy, precision, and traceability of the data products.
4. automating operations (observations, data processing, quality assurance/quality control (QA/QC), etc.) where possible to lower costs.

5. developing more compact, mobile, and less expensive instruments to enhance their deployment in developing countries, remote locations, and for campaign purposes.

6. closer work with the modelling community to evaluate chemistry-climate modules (cf. the Chemistry-Climate Model Initiative (CCMI); Morgenstern et al., 2017) and chemical-transport models.

7. providing early warning of volcanic eruptions using various NDACC instruments, especially in conditions of compromised satellite observations.

In all of these activities, NDACC is committed to interaction with a range of user communities who recognize the value of ground-based observations.

Data availability. All NDACC data more than 1 year old are public data; additionally some PIs have authorized their data for early release. This public record is available through an anonymous ftp at ftp.cpc.ncep.noaa.gov/ndacc. For some projects it is of value to offer data to the scientific community with a maximum delay of 1 month. If these rapid delivery data are of lesser quality than traditional NDACC certified data, if the data have not yet been quality controlled, or if the data are less complete (e.g. missing uncertainty estimates), then these data are identified as "Rapid Delivery (RD)"; they are available separately on the NDACC public website at ftp.cpc.ncep.noaa.gov/ndacc/RD. As soon as the standard verified version is available, the RD data will be removed and the fully verified version will be archived in the NDACC archive. 


\section{Appendix A}

Table A1. Inventory of papers in this special issue, categorized by atmospheric domain, theme (main species addressed) and topic.

\begin{tabular}{|c|c|c|c|c|c|}
\hline Authors & Title & $\begin{array}{l}\text { Working } \\
\text { Group }\end{array}$ & Domain & Theme & Topic \\
\hline Bader et al. (2017) & $\begin{array}{l}\text { The recent increase in atmospheric methane from } 10 \\
\text { years of ground-based NDACC FTIR observations since } \\
2005\end{array}$ & IR & $\begin{array}{l}\text { troposphere } \\
\text { \& strato- } \\
\text { sphere }\end{array}$ & $\mathrm{CH}_{4}$ & trends \\
\hline $\begin{array}{l}\text { Barthlott et } \\
\text { al. (2017) }\end{array}$ & $\begin{array}{l}\text { Tropospheric water vapour isotopologue data }\left(\mathrm{H}_{2}^{16} \mathrm{O} \text {, }\right. \\
\left.\mathrm{H}_{2}^{18} \mathrm{O} \text {, and } \mathrm{HD}^{16} \mathrm{O}\right) \text { as obtained from NDACC/FTIR so- } \\
\text { lar absorption spectra }\end{array}$ & IR & troposphere & water vapour & technique \\
\hline $\begin{array}{l}\text { Baylon et } \\
\text { al. (2017) }\end{array}$ & $\begin{array}{l}\text { Background } \mathrm{CO}_{2} \text { levels and error analysis from ground- } \\
\text { based solar absorption IR measurements in central Mex- } \\
\text { ico }\end{array}$ & IR & troposphere & $\mathrm{CO}_{2}$ & technique \\
\hline $\begin{array}{l}\text { Blanchard et } \\
\text { al. (2017) }\end{array}$ & $\begin{array}{l}\text { Thin ice clouds in the Arctic: cloud optical depth and } \\
\text { particle size retrieved from ground-based thermal in- } \\
\text { frared radiometry }\end{array}$ & IR & troposphere & clouds & technique \\
\hline $\begin{array}{l}\text { Brogniez et } \\
\text { al. }(2016)\end{array}$ & $\begin{array}{l}\text { Validation of satellite-based noontime UVI (ultraviolet } \\
\text { index) with } \\
\text { NDACC ground-based instruments: influence of topog- } \\
\text { raphy, environment and satellite overpass time }\end{array}$ & spectral UV & $\begin{array}{l}\text { troposphere } \\
\& \text { strato- } \\
\text { sphere }\end{array}$ & UVI & validation \\
\hline $\begin{array}{l}\text { Buchholz et } \\
\text { al. (2017) }\end{array}$ & $\begin{array}{l}\text { Validation of MOPITT (Measurement of Pollution in } \\
\text { The Troposphere) carbon monoxide using ground- } \\
\text { based Fourier transform infrared spectrometer data from } \\
\text { NDACC }\end{array}$ & IR & $\begin{array}{l}\text { troposphere } \\
\& \text { strato- } \\
\text { sphere }\end{array}$ & $\mathrm{CO}$ & validation \\
\hline $\begin{array}{l}\text { Christiansen et } \\
\text { al. (2017) }\end{array}$ & $\begin{array}{l}\text { Trends and annual cycles in soundings of Arctic tropo- } \\
\text { spheric ozone }\end{array}$ & sonde & troposphere & ozone & trends \\
\hline $\begin{array}{l}\text { Deshler et } \\
\text { al. (2017) }\end{array}$ & $\begin{array}{l}\text { Methods to homogenize electrochemical concentration } \\
\text { cell (ECC) ozone-sonde measurements across changes } \\
\text { in sensing solution concentration or ozone-sonde man- } \\
\text { ufacturer }\end{array}$ & sonde & $\begin{array}{l}\text { troposphere } \\
\& \text { strato- } \\
\text { sphere }\end{array}$ & ozone & technique \\
\hline $\begin{array}{l}\text { Douglass et } \\
\text { al. (2017) }\end{array}$ & $\begin{array}{l}\text { Multi-decadal records of stratospheric composition and } \\
\text { their relationship to stratospheric circulation change }\end{array}$ & $\begin{array}{l}\text { Theory \& } \\
\text { Analysis }\end{array}$ & stratosphere & circulation & trends \\
\hline $\begin{array}{l}\text { Duflot et } \\
\text { al. (2017) }\end{array}$ & $\begin{array}{l}\text { Tropospheric ozone profiles by DIAL at Maïdo Obser- } \\
\text { vatory (Reunion Island): system description, instrumen- } \\
\text { tal performance and result comparison with ozone ex- } \\
\text { ternal data set }\end{array}$ & Lidar & troposphere & ozone & technique \\
\hline $\begin{array}{l}\text { Evans et } \\
\text { al. (2017) }\end{array}$ & $\begin{array}{l}\text { Technical note: The US Dobson station network data } \\
\text { record prior to 2015, re-evaluation of NDACC and } \\
\text { WOUDC archived records with WinDobson processing } \\
\text { software }\end{array}$ & $\begin{array}{l}\text { Brewer- } \\
\text { Dobson }\end{array}$ & $\begin{array}{l}\text { troposphere } \\
\& \text { strato- } \\
\text { sphere }\end{array}$ & ozone & technique \\
\hline $\begin{array}{l}\text { Fernandez et } \\
\text { al. (2016) }\end{array}$ & $\begin{array}{l}\text { Results from the validation campaign of the ozone } \\
\text { radiometer GROMOS(GROund-based Millimeter-wave } \\
\text { Ozone Spectrometer)-C at the NDACC station of Réu- } \\
\text { nion island }\end{array}$ & microwave & stratosphere & ozone & validation \\
\hline $\begin{array}{l}\text { Granados-Munoz } \\
\text { et al. (2016) }\end{array}$ & $\begin{array}{l}\text { Tropospheric ozone seasonal and long-term variability } \\
\text { as seen by lidar and surface measurements at the JPL } \\
\text { Table Mountain Facility, California }\end{array}$ & lidar & troposphere & ozone & trends \\
\hline $\begin{array}{l}\text { Hausmann et } \\
\text { al. (2017) }\end{array}$ & $\begin{array}{l}\text { A decadal time series of water vapour and } \mathrm{D} / \mathrm{H} \text { isotope } \\
\text { ratios above Zugspitze: transport patterns to central Eu- } \\
\text { rope }\end{array}$ & IR & troposphere & water vapour & trends \\
\hline $\begin{array}{l}\text { Hausmann et } \\
\text { al. (2016) }\end{array}$ & $\begin{array}{l}\text { Contribution of oil and natural gas production to re- } \\
\text { newed increase in atmospheric methane (2007-2014): } \\
\text { top-down estimate from ethane and methane column } \\
\text { observations }\end{array}$ & IR & troposphere & methane & trends \\
\hline $\begin{array}{l}\text { Khaykin et } \\
\text { al. (2017) }\end{array}$ & $\begin{array}{l}\text { Variability and evolution of the midlatitude strato- } \\
\text { spheric aerosol budget from } 22 \text { years of ground-based } \\
\text { lidar and satellite observations }\end{array}$ & lidar & stratosphere & aerosol & trends \\
\hline Kiel et al. (2016) & $\begin{array}{l}\text { Comparison of XCO abundances from the Total Carbon } \\
\text { Column Observing Network and the Network for the } \\
\text { Detection of Atmospheric Composition Change mea- } \\
\text { sured in Karlsruhe }\end{array}$ & IR & $\begin{array}{l}\text { troposphere } \\
\& \text { strato- } \\
\text { sphere }\end{array}$ & $\mathrm{CO}$ & validation \\
\hline Knepp et al. (2017) & $\begin{array}{l}\text { Intercomparison of Pandora Stratospheric } \mathrm{NO}_{2} \text { Slant } \\
\text { Column Product with the NIWA (National Institute of } \\
\text { Water and Atmospheric Research (New Zealand)) M07 } \\
\text { NDACC Standard }\end{array}$ & UV-visible & stratosphere & $\mathrm{NO}_{2}$ & validation \\
\hline
\end{tabular}


Table A1. Continued.

\begin{tabular}{|c|c|c|c|c|c|}
\hline Authors & Title & $\begin{array}{l}\text { Working } \\
\text { Group }\end{array}$ & Domain & Theme & Topic \\
\hline $\begin{array}{l}\text { Leblanc et } \\
\text { al. }(2016)\end{array}$ & $\begin{array}{l}\text { Proposed standardized definitions for vertical resolution } \\
\text { and uncertainty in the NDACC lidar ozone and temper- } \\
\text { ature algorithms - Part 3: Temperature uncertainty bud- } \\
\text { get }\end{array}$ & lidar & stratosphere & temperature & technique \\
\hline $\begin{array}{l}\text { Leblanc et } \\
\text { al. (2016) }\end{array}$ & $\begin{array}{l}\text { Proposed standardized definitions for vertical resolution } \\
\text { and uncertainty in the NDACC lidar ozone and temper- } \\
\text { ature algorithms - Part 2: Ozone DIAL uncertainty bud- } \\
\text { get }\end{array}$ & lidar & stratosphere & ozone & technique \\
\hline $\begin{array}{l}\text { Leblanc } \\
\text { al. }(2016)\end{array}$ & $\begin{array}{l}\text { Proposed standardized definitions for vertical resolution } \\
\text { and uncertainty in the NDACC lidar ozone and temper- } \\
\text { ature algorithms - Part 1: Vertical resolution }\end{array}$ & lidar & stratosphere & $\begin{array}{l}\text { ozone \& tem- } \\
\text { perature }\end{array}$ & technique \\
\hline Mevi et al. (2018) & $\begin{array}{l}\text { VESPA-22 (water Vapor Emission Spectrometer for } \\
\text { Polar Atmosphere at } 22 \mathrm{GHz} \text { ): a ground-based mi- } \\
\text { crowave spectrometer for long-term measurements of } \\
\text { Polar stratospheric water vapour }\end{array}$ & Microwave & stratosphere & water vapour & technique \\
\hline $\begin{array}{l}\text { Moreira et } \\
\text { al. }(2017)\end{array}$ & $\begin{array}{l}\text { Comparison of ozone profiles and influences from the } \\
\text { tertiary ozone maximum in the night-to-day ratio above } \\
\text { Switzerland }\end{array}$ & Microwave & stratosphere & ozone & variability \\
\hline $\begin{array}{l}\text { Moreira et } \\
\text { al. }(2016)\end{array}$ & $\begin{array}{l}\text { The natural oscillations in stratospheric ozone observed } \\
\text { by the GROMOS microwave radiometer at the NDACC } \\
\text { station Bern }\end{array}$ & microwave & stratosphere & ozone & variability \\
\hline $\begin{array}{l}\text { Nedoluha et } \\
\text { al. (2016) }\end{array}$ & $\begin{array}{l}20 \text { years of } \mathrm{ClO} \text { measurements in the Antarctic lower } \\
\text { stratosphere }\end{array}$ & microwave & stratosphere & $\mathrm{ClO}$ & trends \\
\hline $\begin{array}{l}\text { Peters et } \\
\text { al. (2017) }\end{array}$ & $\begin{array}{l}\text { Investigating differences in DOAS retrieval codes using } \\
\text { MAD-CAT campaign data }\end{array}$ & UV-visible & $\begin{array}{l}\text { troposphere } \\
\& \text { strato- } \\
\text { sphere }\end{array}$ & $\mathrm{NO}_{2}$ & technique \\
\hline $\begin{array}{l}\text { Reichert et } \\
\text { al. }(2016)\end{array}$ & $\begin{array}{l}\text { The Zugspitze radiative closure experiment for quanti- } \\
\text { fying water vapour absorption over the terrestrial and } \\
\text { solar infrared - Part } 2 \text { : Accurate calibration of high } \\
\text { spectral-resolution infrared measurements of surface so- } \\
\text { lar radiation }\end{array}$ & IR & troposphere & water vapour & validation \\
\hline $\begin{array}{l}\text { Reichert et } \\
\text { al. }(2016)\end{array}$ & $\begin{array}{l}\text { The Zugspitze radiative closure experiment for quanti- } \\
\text { fying water vapour absorption over the terrestrial and } \\
\text { solar infrared - Part 3: Quantification of the mid- and } \\
\text { near-infrared water vapour continuum in the } 2500 \text { to } \\
7800 \mathrm{~cm}^{-1} \text { spectral range under atmospheric condition }\end{array}$ & IR & troposphere & water vapour & validation \\
\hline $\begin{array}{l}\text { Steinbrecht et } \\
\text { al. (2017) }\end{array}$ & $\begin{array}{l}\text { An update on ozone profile trends for the period } 2000 \\
\text { to } 2016\end{array}$ & NDACC & stratosphere & ozone & trends \\
\hline $\begin{array}{l}\text { Sussmann et } \\
\text { al. (2016) }\end{array}$ & $\begin{array}{l}\text { The Zugspitze radiative closure experiment for quanti- } \\
\text { fying water vapour absorption over the terrestrial and } \\
\text { solar infrared - Part 1: Setup, uncertainty analysis, and } \\
\text { assessment of far-infrared water vapour continuum }\end{array}$ & IR & troposphere & water vapour & validation \\
\hline Toon et al. (2017) & $\begin{array}{l}\text { Measurements of atmospheric ethene by solar absorp- } \\
\text { tion FTIR spectrometry }\end{array}$ & IR & troposphere & ethene & trends \\
\hline Toon et al. (2018) & $\begin{array}{l}\text { Atmospheric carbonyl sulfide (OCS) measured re- } \\
\text { motely by FTIR solar absorption spectrometer }\end{array}$ & IR & $\begin{array}{l}\text { troposphere } \\
\text { \& strato- } \\
\text { sphere }\end{array}$ & OCS & trends \\
\hline $\begin{array}{l}\text { Van Malderen et } \\
\text { al. (2016) }\end{array}$ & $\begin{array}{l}\text { On instrumental errors and related correction strategies } \\
\text { of ozone-sondes: possible effect on calculated ozone } \\
\text { trends for the nearby sites Uccle and De Bilt }\end{array}$ & sonde & $\begin{array}{l}\text { troposphere } \\
\& \text { strato- } \\
\text { sphere }\end{array}$ & ozone & technique \\
\hline $\begin{array}{l}\text { Virolainen et } \\
\text { al. (2017) }\end{array}$ & $\begin{array}{l}\text { Quality assessment of integrated water vapour measure- } \\
\text { ments at St. Petersburg site, Russia: FTIR vs. MW (mil- } \\
\text { limetre wave) and GPS techniques }\end{array}$ & NDACC & $\begin{array}{l}\text { troposphere } \\
\& \text { strato- } \\
\text { sphere }\end{array}$ & water vapour & validation \\
\hline $\begin{array}{l}\text { Weaver et } \\
\text { al. (2017) }\end{array}$ & $\begin{array}{l}\text { Intercomparison of atmospheric water vapour measure- } \\
\text { ments at a Canadian High Arctic site }\end{array}$ & NDACC & $\begin{array}{l}\text { troposphere } \\
\& \text { strato- } \\
\text { sphere }\end{array}$ & water vapour & validation \\
\hline $\begin{array}{l}\text { Yela et } \\
\text { al. (2017) }\end{array}$ & Hemispheric asymmetry in stratospheric $\mathrm{NO}_{2}$ trends & UV-visible & stratosphere & $\mathrm{NO}_{2}$ & variability \\
\hline
\end{tabular}


Table A1. Continued.

\begin{tabular}{|c|c|c|c|c|c|}
\hline Authors & Title & $\begin{array}{l}\text { Working } \\
\text { group }\end{array}$ & Domain & Theme & Topic \\
\hline Zeng et al. (2017) & $\begin{array}{l}\text { Attribution of recent ozone changes in the Southern } \\
\text { Hemisphere midlatitudes using statistical analysis and } \\
\text { chemistry-climate model simulations }\end{array}$ & $\begin{array}{l}\text { Theory \& } \\
\text { Analysis }\end{array}$ & \multirow{3}{*}{$\begin{array}{l}\text { troposphere } \\
\text { \& strato- } \\
\text { sphere } \\
\text { troposphere } \\
\text { \& strato- } \\
\text { sphere } \\
\text { troposphere }\end{array}$} & ozone & trends \\
\hline Zhao et al. (2016) & $\begin{array}{l}\text { Accuracy, precision, and temperature dependence of } \\
\text { Pandora total ozone measurements estimated from a } \\
\text { comparison with the Brewer triad in Toronto }\end{array}$ & UV-visible & & ozone & validation \\
\hline Zhou et al. (2016) & $\begin{array}{l}\text { CFC-11, CFC-12 and HCFC- } 22 \text { ground-based remote- } \\
\text { sensing FTIR measurements at Réunion Island and } \\
\text { comparisons with MIPAS (Michelson Interferometer } \\
\text { for Passive Atmospheric Sounding)/Envisat data }\end{array}$ & IR & & $(\mathrm{H}) \mathrm{CFC}$ & validation \\
\hline
\end{tabular}


Competing interests. The authors declare that they have no conflict of interest.

Special issue statement. This article is part of the special issue "Twenty-five years of operations of the Network for the Detection of Atmospheric Composition Change (NDACC) (AMT/ACP/ESSD inter-journal SI)". It is not associated with a conference.

Acknowledgements. Since its early years, NDSC/NDACC has received outstanding administrative support from Kathy A. Thompson (SSAI, Lanham, MD, USA). US support for NDSC/NDACC instruments and sites, for construction and maintenance of the database, and for some of the Cooperating Networks has been provided by NASA through UARP and related programs (Michael J. Kurylo and Kenneth W. Jucks, program managers) and by NOAA/OGP, NOAA/ESRL, and NOAA/NCDC (now NCEI). Particular recognition goes to Jen-Jeng (Roger) Lin and Jeannette D. Wild (NOAA CPC/INNOVIM, College Park, MD, USA) for their tireless efforts in support of the database and Data Host Facility. In Europe, NDSC/NDACC activities have been supported through the European Commission Framework Programmes. The NDSC/NDACC PIs are also grateful to ESA and EUMETSAT for support for dedicated campaigns and satellite validation and to their national funding authorities and space agencies. Some support has also been received from JAXA and Japanese authorities for NDACC sites in Japan and South America (Rio Gallegos) and for the validation of Japanese satellite missions. While the co-authors, most of whom are members of the NDACC Steering Committee, provided significant input to this paper, they thank all NDACC PIs and all current and past members of the NDACC Steering Committee listed here for their important efforts dedicated to the network: Daniel L. Albritton, Georgios T. Amanatidis, Richard M. Bevilacqua, Gregory E. Bodeker, Bojan Bojkov, Rumen D. Bojkov, Claus Brüning, James H. Butler, Francesco Cairo, Martyn Chipperfield, Michele Colacino, R. Anthony Cox, Phil L. DeCola, Angelika Dehn, Jérôme de La Noë, Terry Deshler, Ruud Dirksen, Jean-François Doussin, Amelie Driemel, James R. Drummond, Ellsworth G. Dutton, James W. Elkins II, Hans Fast, JeanMarie Flaud, Giorgio Giovanelli, Sophie Godin-Beekmann, Lesley Gray, Aleksandr N. Gruzdev, William Hill, David J. Hofmann, Dale F. Hurst, Franz Immler, Jose M. Jimenez Mingo, Bryan J. Johnson, Paul V. Johnston, Torben S. Jørgensen, Sylvie Joussaume, Niklaus Kämpfer, Vyacheslav U. Khattatov, Ulf Köhler, Gert König-Langlo, Robert M. Koopman, Karin Kreher, Klaus F. Künzi, Niels Larsen, Charles N. Long, Emmanuel Mahieu, William G. Mankin, Hal B. Maring, W. Andrew Matthews, I. Stuart McDermid, C. Thomas McElroy, Gérard Mégie, Joseph Michalsky, Pauline M. Midgley, A. James Miller, Akira Mizuno, Frank J. Murcray, Hideaki Nakane, Paul A. Newman, Justus Notholt, Samuel J. Oltmans, Heinrich Ott, Nicole Papineau, Jean-Pierre Pommereau, Ronald G. Prinn, Michael H. Proffitt, William J. Randel, Alberto Redondas Marrero, Clive D. Rodgers, James M. Russell III, Nelson A. Sabogal, Yasuhiro Sasano, Vladimir Savastiouk, Holger Schmithüsen, Russell C. Schnell, Otto Schrems, Masato Shiotani, Björn-Martin Sinnhuber, Susan Solomon, René Stübi, Ralf Sussmann, Daan P. J. Swart, Peter W. Thorne, Michel Van Roozendael, D. Vidal-Madjar,
Holger Vömel, Peter von der Gathen, Emanuele Vuerich, David Wardle, Robert T. Watson, Ray F. Weiss, Paul O. Wennberg, Peter T. Woods, Rodolphe J. Zander, and Claus Zehner. They also thank Colette Brogniez (Université Lille 1 - Sciences et Technologies, Villeneuve d'Ascq, France), Richard L. McKenzie (National Institute of Water \& Atmospheric Research (NIWA), Lauder, New Zealand), and Stana Simic (University of Natural Resources and Life Sciences, Vienna, Austria), who contributed to Sect. 3.6 and provided data for Fig. 13.

Edited by: Vincent-Henri Peuch

Reviewed by: two anonymous referees

\section{References}

Ackerman, M., Frimout, D., Muller, C., Nevejans, D., Fontanella, J. C., Girard, A., Gramont, L., and Louisnard, N.: Recent Stratospheric Spectra of $\mathrm{NO}$ and $\mathrm{NO}_{2}$, Can. J. Chem., 52, 1532-1535, https://doi.org/10.1139/v74-225, 1974.

Anderson, G. P., Barth, C. A., Cayla, F., and London, J.: Satellite observations of the vertical ozone distribution in the upper stratosphere, Ann. Géophys., 25, 341-345, 1969.

Antón, M., López, M., Vilaplana, J. M., Kroon, M., McPeters, R., Bañón, M., and Serrano, A.: Validation of OMI-TOMS and OMIDOAS total ozone column using five Brewer spectroradiometers at the Iberian peninsula, J. Geophys. Res., 114, D14307, https://doi.org/10.1029/2009JD012003, 2009.

Bais, A. F., McKenzie, R. L., Bernhard, G., Aucamp, P. J., Ilyas, M., Madronich, S., and Tourpali, K.: Ozone depletion and climate change: impacts on UV radiation, Photoch. Photobio. Sci., 14, 19-52, 2015.

Bak, J., Liu, X., Kim, J. H., Chance, K., and Haffner, D. P.: Validation of OMI total ozone retrievals from the SAO ozone profile algorithm and three operational algorithms with Brewer measurements, Atmos. Chem. Phys., 15, 667-683, https://doi.org/10.5194/acp-15-667-2015, 2015.

Barthlott, S., Schneider, M., Hase, F., Wiegele, A., Christner, E., González, Y., Blumenstock, T., Dohe, S., García, O. E., Sepúlveda, E., Strong, K., Mendonca, J., Weaver, D., Palm, M., Deutscher, N. M., Warneke, T., Notholt, J., Lejeune, B., Mahieu, E., Jones, N., Griffith, D. W. T., Velazco, V. A., Smale, D., Robinson, J., Kivi, R., Heikkinen, P., and Raffalski, U.: Using $\mathrm{XCO}_{2}$ retrievals for assessing the long-term consistency of NDACC/FTIR data sets, Atmos. Meas. Tech., 8, 1555-1573, https://doi.org/10.5194/amt-8-1555-2015, 2015.

Barthlott, S., Schneider, M., Hase, F., Blumenstock, T., Kiel, M., Dubravica, D., García, O. E., Sepúlveda, E., Mengistu Tsidu, G., Takele Kenea, S., Grutter, M., Plaza-Medina, E. F., Stremme, W., Strong, K., Weaver, D., Palm, M., Warneke, T., Notholt, J., Mahieu, E., Servais, C., Jones, N., Griffith, D. W. T., Smale, D., and Robinson, J.: Tropospheric water vapour isotopologue data $\left(\mathrm{H}_{2}^{16} \mathrm{O}, \mathrm{H}_{2}^{18} \mathrm{O}\right.$, and $\left.\mathrm{HD}^{16} \mathrm{O}\right)$ as obtained from NDACC/FTIR solar absorption spectra, Earth Syst. Sci. Data, 9, 15-29, https://doi.org/10.5194/essd-9-15-2017, 2017.

Bass, A. M. and Paur, R. J.: The ultraviolet cross-sections of ozone: I, The measurements, in: Atmospheric Ozone - Proceedings of the Quadrennial Ozone Symposium 1984, edited by: Zerefos, 
C. S. and Ghazi, A., 606-610, Dordrecht Reidel, Norwell, MA, 1985.

Bates, D. R. and Nicolet, M.: The photochemistry of atmospheric water vapor, J. Geophys. Res., 55, 301-327, 1950.

Bernhard, G., Booth, C. R., and Ehramjian, J. C.: Comparison of UV irradiance measurements at Summit, Greenland; Barrow, Alaska; and South Pole, Antarctica, Atmos. Chem. Phys., 8, 4799-4810, https://doi.org/10.5194/acp-8-4799-2008, 2008.

Bernhard, G., Booth, C. R., and Ehramjian, J. C.: Climatology of Ultraviolet Radiation at High Latitudes Derived from Measurements of the National Science Foundation's Ultraviolet Spectral Irradiance Monitoring Network, in: UV Radiation in Global Climate Change: Measurements, Modeling and Effects on Ecosystems, edited by: Gao, W., Schmoldt, D. L., and Slusser, J. R., Tsinghua University Press, Beijing and Springer, New York, 544 pp., ISBN 978-3-642-03312-4, 2010.

Braathen, G. O.: NDACC Newsletter, published by NDACC Steering Committee, 6, 13-15, available at: http://www.ndsc.ncep. noaa.gov/news/archives/nl2015-8.pdf (last access: 2 April 2018), 2015

Brogniez, C., Auriol, F., Deroo, C., Arola, A., Kujanpää, J., Sauvage, B., Kalakoski, N., Pitkänen, M. R. A., Catalfamo, M., Metzger, J.-M., Tournois, G., and Da Conceicao, P.: Validation of satellite-based noontime UVI with NDACC groundbased instruments: influence of topography, environment and satellite overpass time, Atmos. Chem. Phys., 16, 15049-15074, https://doi.org/10.5194/acp-16-15049-2016, 2016.

Cadle, R. D., Crutzen, P. J., and Ehhalt, D. H.: Heterogeneous Chemical Reactions in the Stratosphere, J. Geophys. Res., 80, 3381-3385, 1975.

Cicerone, R. J., Stolarski, R. S., and Walters, S., Stratospheric ozone destruction by man-made chlorofluoromethanes, Science, 186, 1165-1167, 1974

Clerbaux, C., George, M., Turquety, S., Walker, K. A., Barret, B., Bernath, P., Boone, C., Borsdorff, T., Cammas, J. P., Catoire, V., Coffey, M., Coheur, P.-F., Deeter, M., De Mazière, M., Drummond, J., Duchatelet, P., Dupuy, E., de Zafra, R., Eddounia, F., Edwards, D. P., Emmons, L., Funke, B., Gille, J., Griffith, D. W. T., Hannigan, J., Hase, F., Höpfner, M., Jones, N., Kagawa, A., Kasai, Y., Kramer, I., Le Flochmoën, E., Livesey, N. J., López-Puertas, M., Luo, M., Mahieu, E., Murtagh, D., Nédélec, P., Pazmino, A., Pumphrey, H., Ricaud, P., Rinsland, C. P., Robert, C., Schneider, M., Senten, C., Stiller, G., Strandberg, A., Strong, K., Sussmann, R., Thouret, V., Urban, J., and Wiacek, A.: CO measurements from the ACE-FTS satellite instrument: data analysis and validation using ground-based, airborne and spaceborne observations, Atmos. Chem. Phys., 8, 2569-2594, https://doi.org/10.5194/acp-8-2569-2008, 2008.

Connor, B. J., Mooney, T., Nedoluha, G. E., Barrett, J. W., Parrish, A., Koda, J., Santee, M. L., and Gomez, R. M.: Re-analysis of ground-based microwave $\mathrm{ClO}$ measurements from Mauna Kea, 1992 to early 2012, Atmos. Chem. Phys., 13, 8643-8650, https://doi.org/10.5194/acp-13-8643-2013, 2013.

Crutzen, P. J.: Estimates of Possible Future Ozone Reductions from Continued Use of Fluorochloromethanes $\left(\mathrm{CF}_{2} \mathrm{Cl}_{2}, \mathrm{CFCl}_{3}\right)$, Geophys. Res. Lett., 1, 205-208, 1974a.

Crutzen, P. J.: Estimates of Possible Variations in Total Ozone due to Natural Causes and Human Activities, Ambio, 3, 201-210, $1974 b$
De Mazière, M., Van Roozendael, M., Bojkov, B. R., de la Noë, J., Mahieu, E., and Neuber, R.: Archiving of atmospheric data: Data formats and database, in IRS 2000: Current Problems in Atmospheric Radiation, edited by: Smith, W. L., Yu, M., and Timofeyev, A., Deepak Publishing, Hampton, Virginia, 1019-1022, 2002.

De Mazière, M., Vigouroux, C., Bernath, P. F., Baron, P., Blumenstock, T., Boone, C., Brogniez, C., Catoire, V., Coffey, M., Duchatelet, P., Griffith, D., Hannigan, J., Kasai, Y., Kramer, I., Jones, N., Mahieu, E., Manney, G. L., Piccolo, C., Randall, C., Robert, C., Senten, C., Strong, K., Taylor, J., Tétard, C., Walker, K. A., and Wood, S.: Validation of ACE-FTS v2.2 methane profiles from the upper troposphere to the lower mesosphere, Atmos. Chem. Phys., 8, 2421-2435, https://doi.org/10.5194/acp-8-24212008, 2008.

Deshler, T., Mercer, J., Smit, H. G. J., Johnson, B. J., Oltmans, S. J., Stuebi, R., Levrat, G., Davies, J., Thompson, A. M., Witte, J., Schmidlin, F. J., Brothers, G., Toru, S., and Proffitt, M.: Balloon Experiment to Test ECC-ozonesondes from Different Manufacturers and with Different Cathode Solution Strengths: Results of the BESOS flight, J. Geophys. Res., 113, D04307, https://doi.org/10.1029/2007JD008975, 2008.

Deshler, T., Stübi, R., Schmidlin, F. J., Mercer, J. L., Smit, H. G. J., Johnson, B. J., Kivi, R., and Nardi, B.: Methods to homogenize electrochemical concentration cell (ECC) ozonesonde measurements across changes in sensing solution concentration or ozonesonde manufacturer, Atmos. Meas. Tech., 10, 2021-2043, https://doi.org/10.5194/amt-10-2021-2017, 2017.

Douglass, A. R., Strahan, S. E., Oman, L. D., and Stolarski, R. S.: Understanding differences in chemistry climate model projections of stratospheric ozone, J. Geophys. Res.-Atmos., 119, 4922-4939, https://doi.org/10.1002/2013JD021159, 2014.

Dupuy, E., Walker, K. A., Kar, J., Boone, C. D., McElroy, C. T., Bernath, P. F., Drummond, J. R., Skelton, R., McLeod, S. D., Hughes, R. C., Nowlan, C. R., Dufour, D. G., Zou, J., Nichitiu, F., Strong, K., Baron, P., Bevilacqua, R. M., Blumenstock, T., Bodeker, G. E., Borsdorff, T., Bourassa, A. E., Bovensmann, H., Boyd, I. S., Bracher, A., Brogniez, C., Burrows, J. P., Catoire, V., Ceccherini, S., Chabrillat, S., Christensen, T., Coffey, M. T., Cortesi, U., Davies, J., De Clercq, C., Degenstein, D. A., De Mazière, M., Demoulin, P., Dodion, J., Firanski, B., Fischer, H., Forbes, G., Froidevaux, L., Fussen, D., Gerard, P., GodinBeekmann, S., Goutail, F., Granville, J., Griffith, D., Haley, C. S., Hannigan, J. W., Höpfner, M., Jin, J. J., Jones, A., Jones, N. B., Jucks, K., Kagawa, A., Kasai, Y., Kerzenmacher, T. E., Kleinböhl, A., Klekociuk, A. R., Kramer, I., Küllmann, H., Kuttippurath, J., Kyrölä, E., Lambert, J.-C., Livesey, N. J., Llewellyn, E. J., Lloyd, N. D., Mahieu, E., Manney, G. L., Marshall, B. T., McConnell, J. C., McCormick, M. P., McDermid, I. S., McHugh, M., McLinden, C. A., Mellqvist, J., Mizutani, K., Murayama, Y., Murtagh, D. P., Oelhaf, H., Parrish, A., Petelina, S. V., Piccolo, C., Pommereau, J.-P., Randall, C. E., Robert, C., Roth, C., Schneider, M., Senten, C., Steck, T., Strandberg, A., Strawbridge, K. B., Sussmann, R., Swart, D. P. J., Tarasick, D. W., Taylor, J. R., Tétard, C., Thomason, L. W., Thompson, A. M., Tully, M. B., Urban, J., Vanhellemont, F., Vigouroux, C., von Clarmann, T., von der Gathen, P., von Savigny, C., Waters, J. W., Witte, J. C., Wolff, M., and Zawodny, J. M.: Validation of ozone measurements from the Atmospheric Chemistry Experiment (ACE), 
Atmos. Chem. Phys., 9, 287-343, https://doi.org/10.5194/acp-9287-2009, 2009.

European Commission (DG XII): European research in the stratosphere. The contribution of EASOE and SESAME to our current understanding of the ozone layer, EUR 16986 EN, ISBN 92-8279719-8, 1997.

Evans, R. D., Petropavlovskikh, I., McClure-Begley, A., McConville, G., Quincy, D., and Miyagawa, K.: The US Dobson Station Network Data Record Prior to 2015, Re-evaluation of NDACC and WOUDC archived records with WinDobson processing software, Atmos. Chem. Phys., 17, 12051-12070, https://doi.org/10.5194/acp-17-12051-2017, 2017.

Farman, J. C., Gardiner, B. G., and Shanklin, J. D.: Large losses of total ozone in Antarctica reveal seasonal $\mathrm{ClO}_{x} / \mathrm{NO}_{x}$ interaction, Nature, 315, 207-210, https://doi.org/10.1038/315207a0, 1985.

Fioletov, V. E., Labow, G., Evans, R., Hare, E. W., Khler, U., McElroy, C. T., Miyagawa, K., Redondas, A., Savastiouk., V., Shalamyansky, A. M., Staehelin, J., Vanicek, K., and Weber, M.: Performance of the ground-based total ozone network assessed using satellite data, J. Geophys. Res., 113, D14313, https://doi.org/10.1029/2008JD009809, 2008.

Flynn, L. Long, C., Wu, X., Evans, R., Beck, C. T., Petropavlovskikh, I., McConville, G., Yu, W., Zhang, Z., Niu, J., Beach, E., Hao, Y., Pan, C., Sen, B., Novicki, M., Zhou, S., and Seftor, C.: Performance of the Ozone Mapping and Profiler Suite (OMPS) products, J. Geophys. Res.-Atmos., 119, 61816195, https://doi.org/10.1002/2013JD020467, 2014.

Franco, B., Mahieu, E., Emmons, L. K., Tzompa-Sosa, Z. A., Fischer, E. V., Sudo, K., Bovy, B., Conway, S., Griffith, D., Hannigan, J. W., Strong, K., and Walker, K. A.: Evaluating ethane and methane emissions associated with the development of oil and natural gas extraction in North America, Environ. Res. Lett., 11, 044010, https://doi.org/10.1088/1748-9326/11/4/044010, 2016.

Gaines, S. E. and Hipskind R. S.: Format Specification for Data Exchange, Version 1.3, available at: http://www.ndsc.ncep.noaa. gov/data/formats/gaines2.pdf (last access: 2 April 2018), 1998.

Gardiner, T., Forbes, A., de Mazière, M., Vigouroux, C., Mahieu, E., Demoulin, P., Velazco, V., Notholt, J., Blumenstock, T., Hase, F., Kramer, I., Sussmann, R., Stremme, W., Mellqvist, J., Strandberg, A., Ellingsen, K., and Gauss, M.: Trend analysis of greenhouse gases over Europe measured by a network of ground-based remote FTIR instruments, Atmos. Chem. Phys., 8, 6719-6727, https://doi.org/10.5194/acp-8-6719-2008, 2008.

Godin, S., Carswell, A. I., Donovan, D. P., Claude, H., Steinbrecht, W., McDermid, I. S., McGee, T. J., Gross, M. R., Nakane, H., Swart, D. P., and Bergwerff, H. B.: Ozone differential absorption lidar algorithm intercomparison, Appl. Opt., 38, 6225-6236, 1999.

Goldman, A., Paton-Walsh, C., Bell, W., Toon, G. C., Blavier, J.-F., Sen, B., Coffey, M. T., Hannigan, J. W., and Mankin, W. G.: Network for the detection of stratospheric change Fourier transform infrared intercomparison at Table Mountain Facility, J. Geophys. Res.-Atmos., 104, 30481-30503, https://doi.org/10.1029/1999JD900879, 1999.

Gorshelev, V., Serdyuchenko, A., Weber, M., Chehade, W., and Burrows, J. P.: High spectral resolution ozone absorption crosssections - Part 1: Measurements, data analysis and comparison with previous measurements around $293 \mathrm{~K}$, Atmos. Meas. Tech., 7, 609-624, https://doi.org/10.5194/amt-7-609-2014, 2014.
Grobecker, A. J.: Research program for assessment of stratospheric pollution, in: Impact of Aerospace Technology on Studies of the Earth's Atmosphere, edited by: Oppenheim, A. K., Pergamon Press Inc., 1974.

Haefele, A., Hocke, K., Kämpfer, N., Keckhut, P., Marchand, M., Bekki, S., Morel, B., Egorova, T., and Rozanov, E.: Diurnal changes in middle atmospheric $\mathrm{H}_{2} \mathrm{O}$ and $\mathrm{O}_{3}$ : Observations in the Alpine region and climate models, J. Geophys. Res., 113, D17303, https://doi.org/10.1029/2008JD009892, 2008.

Hase, F.: Improved instrumental line shape monitoring for the ground-based, high-resolution FTIR spectrometers of the Network for the Detection of Atmospheric Composition Change, Atmos. Meas. Tech., 5, 603-610, https://doi.org/10.5194/amt-5603-2012, 2012.

Heath, D. F., Mateer, C. L., and Krueger, A. J.: The Nimbus-4 Backscatter Ultraviolet (BUV) Atmospheric Ozone ExperimentTwo Years' Operation, Pure Appl. Geophys., 106-108, 12381253, https://doi.org/10.1007/BF00881076, 1973.

Hubert, D., Lambert, J.-C., Verhoelst, T., Granville, J., Keppens, A., Baray, J.-L., Bourassa, A. E., Cortesi, U., Degenstein, D. A., Froidevaux, L., Godin-Beekmann, S., Hoppel, K. W., Johnson, B. J., Kyrölä, E., Leblanc, T., Lichtenberg, G., Marchand, M., McElroy, C. T., Murtagh, D., Nakane, H., Portafaix, T., Querel, R., Russell III, J. M., Salvador, J., Smit, H. G. J., Stebel, K., Steinbrecht, W., Strawbridge, K. B., Stübi, R., Swart, D. P. J., Taha, G., Tarasick, D. W., Thompson, A. M., Urban, J., van Gijsel, J. A. E., Van Malderen, R., von der Gathen, P., Walker, K. A., Wolfram, E., and Zawodny, J. M.: Ground-based assessment of the bias and long-term stability of 14 limb and occultation ozone profile data records, Atmos. Meas. Tech., 9, 2497-2534, https://doi.org/10.5194/amt-9-2497-2016, 2016.

Hurst, D. F., Oltmans, S. J., Vömel, H., Rosenlof, K. H., Davis, S. M., Ray, E. A., Hall, E. G., and Jordan, A. F.: Stratospheric water vapor trends over Boulder, Colorado: Analysis of the 30 year Boulder record, J. Geophys. Res., 116, D02306, https://doi.org/10.1029/2010JD015065, 2011.

Iozenas, V. A., Krasnopol'skiy, V. A., Kuznetsov, A. P., and Lebedinskiy, A. I.: An investigation of planetary ozone distribution from satellite measurements of ultraviolet spectra, Izv. Atmos. Ocean. Phy.+, 5, 219-233, 1969.

Johnston, H. S.: Reduction of stratospheric ozone by nitrogen oxide catalysts from supersonic transport exhaust, Science, 173, 517522, 1971.

Kämpfer, N. (Ed.): Monitoring Atmospheric Water Vapour: Ground-Based Remote Sensing and In-situ Methods, ISSI Scientific Report Series, https://doi.org/10.1007/978-1-4614-39097, 2013.

Keckhut, P., McDermid, S., Swart, D., McGee, T., GodinBeekmann, S., Adriani, A., Barnes, J., Baray, J. L., Bencherif, H., Claude, H., and di Sarra, A. G.: Review of ozone and temperature lidar validations performed within the framework of the Network for the Detection of Stratospheric Change, J. Environ. Monitor., 6, 721-733, 2004.

Kerzenmacher, T., Wolff, M. A., Strong, K., Dupuy, E., Walker, K. A., Amekudzi, L. K., Batchelor, R. L., Bernath, P. F., Berthet, G., Blumenstock, T., Boone, C. D., Bramstedt, K., Brogniez, C., Brohede, S., Burrows, J. P., Catoire, V., Dodion, J., Drummond, J. R., Dufour, D. G., Funke, B., Fussen, D., Goutail, F., Griffith, D. W. T., Haley, C. S., Hendrick, F., Höpfner, M., Huret, N., 
Jones, N., Kar, J., Kramer, I., Llewellyn, E. J., López-Puertas, M., Manney, G., McElroy, C. T., McLinden, C. A., Melo, S., Mikuteit, S., Murtagh, D., Nichitiu, F., Notholt, J., Nowlan, C., Piccolo, C., Pommereau, J.-P., Randall, C., Raspollini, P., Ridolfi, M., Richter, A., Schneider, M., Schrems, O., Silicani, M., Stiller, G. P., Taylor, J., Tétard, C., Toohey, M., Vanhellemont, F., Warneke, T., Zawodny, J. M., and Zou, J.: Validation of NO2 and NO from the Atmospheric Chemistry Experiment (ACE), Atmos. Chem. Phys., 8, 5801-5841, https://doi.org/10.5194/acp-8-58012008, 2008.

Kohlhepp, R., Ruhnke, R., Chipperfield, M. P., De Mazière, M., Notholt, J., Barthlott, S., Batchelor, R. L., Blatherwick, R. D., Blumenstock, Th., Coffey, M. T., Demoulin, P., Fast, H., Feng, W., Goldman, A., Griffith, D. W. T., Hamann, K., Hannigan, J. W., Hase, F., Jones, N. B., Kagawa, A., Kaiser, I., Kasai, Y., Kirner, O., Kouker, W., Lindenmaier, R., Mahieu, E., Mittermeier, R. L., Monge-Sanz, B., Morino, I., Murata, I., Nakajima, H., Palm, M., Paton-Walsh, C., Raffalski, U., Reddmann, Th., Rettinger, M., Rinsland, C. P., Rozanov, E., Schneider, M., Senten, C., Servais, C., Sinnhuber, B.-M., Smale, D., Strong, K., Sussmann, R., Taylor, J. R., Vanhaelewyn, G., Warneke, T., Whaley, C., Wiehle, M., and Wood, S. W.: Observed and simulated time evolution of $\mathrm{HCl}, \mathrm{ClONO}_{2}$, and $\mathrm{HF}$ total column abundances, Atmos. Chem. Phys., 12, 3527-3556, https://doi.org/10.5194/acp-12-3527-2012, 2012.

Komhyr, W. D., Grass, R. D., and Leonard, R. K.: Dobson spectrophotometer 83: A standard for total ozone measurements, 1962-1987, J. Geophys. Res., 94, 9847-9861, https://doi.org/10.1029/JD094iD07p09847, 1989.

Koukouli, M. E., Lerot, C., Granville, J., Goutail, F., Lambert, J.-C., Pommereau, J.-P., Balis, D., Zyrichidou, I., Van Roozendael, M., Coldewey-Egbers, M., Loyola, D., Labow, G., Frith, S., Spurr, R., and Zehner, C.: Evaluating a new homogeneous total ozone climate data record from GOME/ERS-2, SCIAMACHY/Envisat, and GOME-2/MetOp-A, J. Geophys. Res., 120, 12296-12312, https://doi.org/10.1002/2015JD023699, 2015.

Koukouli, M. E., Zara, M., Lerot, C., Fragkos, K., Balis, D., van Roozendael, M., Allart, M. A. F., and van der A, R. J.: The impact of the ozone effective temperature on satellite validation using the Dobson spectrophotometer network, Atmos. Meas. Tech., 9, 2055-2065, https://doi.org/10.5194/amt-9-2055-2016, 2016.

Kreher, K., Van Roozendael, M., Hendrick, F., Apituley, A., Dimitropoulou, E., Friess, U., Richter, A., Wagner, T., Ang, L., Anguas, M., Bais, A., Benavent, N., Bognar, K., Borovski, A., Bruchkovsky, I., Cede, A., Chan, K. L., Donner, S., Drosoglou, T., Fayt, C., Finkenzeller, H., Hao, N., Hermans, C., Hoque, S., Irie, H., Jin, J., Johnston, P., Khayyam Butt, J., Khokhar, F., Koenig, T., Ma, J., Mishra, A. K., Navarro-Comas, M., Pazmino, A., Peters, E., Pinharanda, M., Piters, A., Postylyakov, O., Prados, C., Rodriguez, O., Querel, R., Saiz-Lopez, A., Schreier, S., Seyler, A., Spinei, E., Strong, K., Tiefengraber, M., Tirpitz, J.L., Vinod, K., Volkamer, R., Wenig, M., Xie, P., Xu, J., Yela, M., Zhao, X., and Zhuoru, W.: Intercomparison of slant column measurements of $\mathrm{NO}_{2}, \mathrm{O}_{4}, \mathrm{O}_{3}$ and $\mathrm{HCHO}$ by MAX-DOAS and zenith-sky UV-Visible spectrometers, in preparation, Atm. Meas. Tech., 2018.

Kurylo, M. J. and Solomon, S.: United States NASA Administration Upper Atmosphere Research Program and NOAA Climate and Global Change Program, Network for the detection of stratospheric change: a status and implementation report, NASA, Washington, D.C., 1990.

Kurylo, M. J., Thompson, A. M., and De Mazière, M.: The Network for the Detection of Atmospheric Composition Change: 25 Years Old and Going Strong, The Earth Observer, 28, 4-15, 2016.

Lambert, J.-C., Van Roozendael, M., De Mazière, M., Simon, P. C., Pommereau, J.-P., Goutail, F., Sarkissian, A., and Gleason, J. F.: Investigation of Pole-to-Pole Performances of Spaceborne Atmospheric Chemistry Sensors with the NDSC, J. Atmos. Sci., 56, 176-193, 1999.

Leblanc, T., McDermid, I. S., Hauchecorne, A., and Keckhut, P.: Evaluation of optimization of lidar temperature analysis algorithms using simulated data, J. Geophys. Res., 103, 6177-6187, 1998.

Leblanc, T., Sica, R. J., van Gijsel, J. A. E., Godin-Beekmann, S., Haefele, A., Trickl, T., Payen, G., and Gabarrot, F.: Proposed standardized definitions for vertical resolution and uncertainty in the NDACC lidar ozone and temperature algorithms Part 1: Vertical resolution, Atmos. Meas. Tech., 9, 4029-4049, https://doi.org/10.5194/amt-9-4029-2016, 2016a.

Leblanc, T., Sica, R. J., van Gijsel, J. A. E., Godin-Beekmann, S., Haefele, A., Trickl, T., Payen, G., and Liberti, G.: Proposed standardized definitions for vertical resolution and uncertainty in the NDACC lidar ozone and temperature algorithms - Part 2: Ozone DIAL uncertainty budget, Atmos. Meas. Tech., 9, 4051-4078, https://doi.org/10.5194/amt-9-4051-2016, $2016 \mathrm{~b}$.

Leblanc, T., Sica, R. J., van Gijsel, J. A. E., Haefele, A., Payen, G., and Liberti, G.: Proposed standardized definitions for vertical resolution and uncertainty in the NDACC lidar ozone and temperature algorithms - Part 3: Temperature uncertainty budget, Atmos. Meas. Tech., 9, 4079-4101, https://doi.org/10.5194/amt9-4079-2016, 2016c.

Mahieu, E., Duchatelet, P., Demoulin, P., Walker, K. A., Dupuy, E., Froidevaux, L., Randall, C., Catoire, V., Strong, K., Boone, C. D., Bernath, P. F., Blavier, J.-F., Blumenstock, T., Coffey, M., De Mazière, M., Griffith, D., Hannigan, J., Hase, F., Jones, N., Jucks, K. W., Kagawa, A., Kasai, Y., Mebarki, Y., Mikuteit, S., Nassar, R., Notholt, J., Rinsland, C. P., Robert, C., Schrems, O., Senten, C., Smale, D., Taylor, J., Tétard, C., Toon, G. C., Warneke, T., Wood, S. W., Zander, R., and Servais, C.: Validation of ACEFTS v2.2 measurements of $\mathrm{HCl}, \mathrm{HF}, \mathrm{CCl}_{3} \mathrm{~F}$ and $\mathrm{CCl}_{2} \mathrm{~F}_{2}$ using space-, balloon- and ground-based instrument observations, Atmos. Chem. Phys., 8, 6199-6221, https://doi.org/10.5194/acp-86199-2008, 2008.

Mahieu, E., Chipperfield, M. P., Notholt, J.,Reddmann, T., Anderson, J., Bernath, P. F., Blumenstock, T., Coffey, M. T., Dhomse, S. S., Feng, W., Franco, B., Froidevaux, L., Griffith, D. W. T., Hannigan, J. W., Hase, F., Hossaini, R., Jones, N. B., Morino, I., Murata, I., Nakajima, H., Palm, M., Paton-Walsh, C., Russell III, J. M., Schneider, M., Servais, C., Smale, D., and Walker, K. A.: Recent Northern Hemisphere stratospheric $\mathrm{HCl}$ increase due to atmospheric circulation changes, Nature, 515, 104-107, https://doi.org/10.1038/nature13857, 2014.

McKenzie, R.: UV radiation in the melanoma capital of the world: What makes New Zealand so different?, AIP Conference Proceedings, 1810, 020003-1-020003-8, https://doi.org/10.1063/1.4975499, AIP Publishing, Melville, NY, 2017. 
McKenzie, R. L., Weinreis, C., Johnston, P. V., Liley, B., Shiona, H., Kotkamp, M., Smale, D., Takegawa, N., and Kondo, Y.: Effects of urban pollution on UV spectral irradiances, Atmos. Chem. Phys., 8, 5683-5697, https://doi.org/10.5194/acp-8-5683-2008, 2008.

McKinlay, A. F. and Diffey, B. L.: A reference action spectrum for ultraviolet induced erythemal in human skin, CIE J., 6, 17-22, 1987.

McPeters, R., Kroon, M., Labow, G. J., Brinksma, E., Balis, D., Petropavlovskikh, I., Veefkind, J. P., Bhartia, P. K., and Levelt, P. F.: Validation of the Aura Ozone Monitoring Instrument total column ozone product, J. Geophys. Res., 113, D15S14, https://doi.org/10.1029/2007JD008802, 2008.

McPeters, R. D. and Labow, G. J.: An assessment of the accuracy of 14.5 years of Nimbus 7 TOMS version 7 ozone data by comparison with the Dobson network, Geophys. Res. Lett., 23, 36953698, https://doi.org/10.1029/96GL03539, 1996.

Meijer, Y. J., Fehr, T., Koopman, R. M., Pellegrini, A., Busswell, G., Williams, I., De Mazière, M., Niemeijer, S., and van Deelen, R.: GECA: ESA's Next Generation Validation Data Centre, in: Proceedings of the 8th International Symposium on Tropospheric Profiling, edited by: Apituley, A., Russchenberg, H. W. J., and Monna, W. A. A., ISBN 978-90-6960-233-2 Delft, the Netherlands, 2009.

Miller, T. L., Smith, S. A., and Kaye, J.: ATLAS Space Shuttle studies Earth's atmosphere and solar input, EOS, 75, 321-325, https://doi.org/10.1029/94EO00974, 1994.

Molina, M. J. and Rowland, F. S.: Stratospheric sink for chlorofluoromethanes: chlorine atom-catalysed destruction of ozone, Nature, 249, 810-812, https://doi.org/10.1038/249810a0, 1974.

Morgenstern, O., Hegglin, M. I., Rozanov, E., O’Connor, F. M., Abraham, N. L., Akiyoshi, H., Archibald, A. T., Bekki, S., Butchart, N., Chipperfield, M. P., Deushi, M., Dhomse, S. S., Garcia, R. R., Hardiman, S. C., Horowitz, L. W., Jöckel, P., Josse, B., Kinnison, D., Lin, M., Mancini, E., Manyin, M. E., Marchand, M., Marécal, V., Michou, M., Oman, L. D., Pitari, G., Plummer, D. A., Revell, L. E., Saint-Martin, D., Schofield, R., Stenke, A., Stone, K., Sudo, K., Tanaka, T. Y., Tilmes, S., Yamashita, Y., Yoshida, K., and Zeng, G.: Review of the global models used within phase 1 of the Chemistry-Climate Model Initiative (CCMI), Geosci. Model Dev., 10, 639-671, https://doi.org/10.5194/gmd-10-639-2017, 2017.

Murcray, D. G., Kyle, T. G., Murcray, F. H., and Williams, W. J.: Nitric acid and nitric oxide in the lower stratosphere, Nature, 218, 78-79, 1968.

Murcray, D. G., Goldman, A., Csoeke-Poeckh, A., Murcray, F. H., Williams, W. J., and Stocker, R. N.: Nitric acid distribution in the stratosphere, J. Geophys. Res., 78, 7033-7038, 1973.

Nedoluha, G. E., Connor, B. J., Barrett, J., Mooney, T., Parrish, A., Boyd, I., Wrotny, J. E., Gomez, R. M., Koda, J., Santee, M., and Froidevaux, L.: Ground-based measurements of $\mathrm{ClO}$ from Mauna Kea and intercomparisons with Aura and UARS MLS, J. Geophys. Res.-Atmos., 116, 2156-2202, https://doi.org/10.1029/2010JD014732, 2011.

Nedoluha, G. E., Michael Gomez, R., Allen, D. R., Lambert, A., Boone, C., and Stiller, G.: Variations in middle atmospheric water vapor from 2004 to 2013, J. Geophys. Res.-Atmos., 118, 11285-11293, https://doi.org/10.1002/jgrd.50834, 2013.
Nedoluha, G. E., Connor, B. J., Mooney, T., Barrett, J. W., Parrish, A., Gomez, R. M., Boyd, I., Allen, D. R., Kotkamp, M., Kremser, S., Deshler, T., Newman, P., and Santee, M. L.: 20 years of ClO measurements in the Antarctic lower stratosphere, Atmos. Chem. Phys., 16, 10725-10734, https://doi.org/10.5194/acp-16-107252016, 2016.

Parrish, A., Boyd, I. S., Nedoluha, G. E., Bhartia, P. K., Frith, S. M., Kramarova, N. A., Connor, B. J., Bodeker, G. E., Froidevaux, L., Shiotani, M., and Sakazaki, T.: Diurnal variations of stratospheric ozone measured by ground-based microwave remote sensing at the Mauna Loa NDACC site: measurement validation and GEOSCCM model comparison, Atmos. Chem. Phys., 14, 7255-7272, https://doi.org/10.5194/acp-14-7255-2014, 2014.

Peters, E., Pinardi, G., Seyler, A., Richter, A., Wittrock, F., Bösch, T., Van Roozendael, M., Hendrick, F., Drosoglou, T., Bais, A. F., Kanaya, Y., Zhao, X., Strong, K., Lampel, J., Volkamer, R., Koenig, T., Ortega, I., Puentedura, O., Navarro-Comas, M., Gómez, L., Yela González, M., Piters, A., Remmers, J., Wang, Y., Wagner, T., Wang, S., Saiz-Lopez, A., García-Nieto, D., Cuevas, C. A., Benavent, N., Querel, R., Johnston, P., Postylyakov, O., Borovski, A., Elokhov, A., Bruchkouski, I., Liu, H., Liu, C., Hong, Q., Rivera, C., Grutter, M., Stremme, W., Khokhar, M. F., Khayyam, J., and Burrows, J. P.: Investigating differences in DOAS retrieval codes using MAD-CAT campaign data, Atmos. Meas. Tech., 10, 955-978, https://doi.org/10.5194/amt-10-9552017, 2017.

Piters, A. J. M., Boersma, K. F., Kroon, M., Hains, J. C., Van Roozendael, M., Wittrock, F., Abuhassan, N., Adams, C., Akrami, M., Allaart, M. A. F., Apituley, A., Beirle, S., Bergwerff, J. B., Berkhout, A. J. C., Brunner, D., Cede, A., Chong, J., Clémer, K., Fayt, C., Frieß, U., Gast, L. F. L., Gil-Ojeda, M., Goutail, F., Graves, R., Griesfeller, A., Großmann, K., Hemerijckx, G., Hendrick, F., Henzing, B., Herman, J., Hermans, C., Hoexum, M., van der Hoff, G. R., Irie, H., Johnston, P. V., Kanaya, Y., Kim, Y. J., Klein Baltink, H., Kreher, K., de Leeuw, G., Leigh, R., Merlaud, A., Moerman, M. M., Monks, P. S., Mount, G. H., Navarro-Comas, M., Oetjen, H., Pazmino, A., Perez-Camacho, M., Peters, E., du Piesanie, A., Pinardi, G., Puentedura, O., Richter, A., Roscoe, H. K., Schönhardt, A., Schwarzenbach, B., Shaiganfar, R., Sluis, W., Spinei, E., Stolk, A. P., Strong, K., Swart, D. P. J., Takashima, H., Vlemmix, T., Vrekoussis, M., Wagner, T., Whyte, C., Wilson, K. M., Yela, M., Yilmaz, S., Zieger, P., and Zhou, Y.: The Cabauw Intercomparison campaign for Nitrogen Dioxide measuring Instruments (CINDI): design, execution, and early results, Atmos. Meas. Tech., 5, 457-485, https://doi.org/10.5194/amt-5457-2012, 2012.

Redondas, A., Evans, R., Stuebi, R., Köhler, U., and Weber, M.: Evaluation of the use of five laboratory-determined ozone absorption cross sections in Brewer and Dobson retrieval algorithms, Atmos. Chem. Phys., 14, 1635-1648, https://doi.org/10.5194/acp-14-1635-2014, 2014.

Rinsland, C. P., Mahieu, E., Zander, R., Jones, N. B., Chipperfield, M. P., Goldman, A., Anderson, J., Russell, J. M., Demoulin, P., Notholt, J., Toon, G. C., Blavier, J.-F., Sen, B., Sussmann, R., Wood, S. W., Meier, A., Griffith, D. W. T., Chiou, L. S., Murcray, F. J., Stephen, T. M., Hase, F., Mikuteit, S., Schulz, A., and Blumenstock, T.: Long-term trends of inorganic chlorine from ground-based infrared solar spectra: Past increases and 
evidence for stabilization, J. Geophys. Res.-Atmos., 108, 42524273, https://doi.org/10.1029/2002JD003001, 2003.

Seckmeyer G., Pissulla, D., Glandorf, M., Henriques, D., Johnsen, B., Webb, A. R., Siani, A.-M., Bais, A., Kjeldstad, B., Brogniez, C., Lenoble, J., Gardiner, B., Kirsch, P., Koskela, T., Kaurola, J., Uhlmann, B., Slaper, H., denOuter, P., Janouch, M., Werle, P., Gröbner, J., Mayer, B., Casiniere, A., Simic, S., and Carvalho, F.: Variability of UV irradiance in Europe, Photochem. Photobiol., 84, 172-179, 2008a.

Seckmeyer G., Glandorf, M., Wichers, C., McKenzie, R. L., Henriques, D., Carvalho, F., Webb, A., Siani, A-M., Bais, A., Kjeldstad, B., Brogniez, C., Werle, P., Koskela, T., Lakkala, K., Gröbner, J., Slaper, H. denOuter, P., and Feister, U.: Europe's darker atmosphere in the UV-B, Photochem. Photobiol. Sci., 7, 925930, 2008b.

Serdyuchenko, A., Gorshelev, V., Weber, M., Chehade, W., and Burrows, J. P.: High spectral resolution ozone absorption crosssections - Part 2: Temperature dependence, Atmos. Meas. Tech., 7, 625-636, https://doi.org/10.5194/amt-7-625-2014, 2014.

Smit, H. G. J. and the Panel for the Assessment of Standard Operating Procedures for Ozonesondes (ASOPOS): Quality assurance and quality control for ozonesonde measurements in GAW, World Meteorological Organization, GAW Report \#201, available at: http://www.wmo.int/pages/prog/arep/ gaw/documents/FINAL_GAW_201_Oct_2014.pdf (last access: 2 April 2018), 2014.

Smit, H. G. J., Straeter, W., Johnson, B. J., Oltmans, S. J., Davies, J., Hoegger, B., Stubi, R., Schmidlin, F. J., Thompson, A. M., Witte, J. C., Boyd, I., and Posny, F.: Assessment of the performance of ECC-ozonesondes under quasi-flight conditions in the environmental simulation chamber: Insights from the Jülich Ozone Sonde Intercomparison Experiment (JOSIE), J. Geophys. Res., 112, D19306, https://doi.org/10.1029/2006JD007308, 2007.

Steinbrecht, W., McGee, T. J., Twigg, L. W., Claude, H., Schönenborn, F., Sumnicht, G. K., and Silbert, D.: Intercomparison of stratospheric ozone and temperature profiles during the October 2005 Hohenpeißenberg Ozone Profiling Experiment (HOPE), Atmos. Meas. Tech., 2, 125-145, https://doi.org/10.5194/amt-2125-2009, 2009.

Sterling, C. W., Johnson, B. J., Oltmans, S. J., Smit, H. G. J., Jordan, A. F., Cullis, P. D., Hall, E. G., Thompson, A. M., and Witte, J. C.: Homogenizing and Estimating the Uncertainty in NOAA's Long Term Vertical Ozone Profile Records Measured with the Electrochemical Concentration Cell Ozonesonde, Atmos. Meas. Tech. Discuss., https://doi.org/10.5194/amt-2017-397, in review, 2017.

Stolarski, R. S. and Cicerone, R. J.: Stratospheric Chlorine: a Possible Sink for Ozone, Can. J. Chem., 52, 1610-1615, 1974.

Strong, K., Wolff, M. A., Kerzenmacher, T. E., Walker, K. A., Bernath, P. F., Blumenstock, T., Boone, C., Catoire, V., Coffey, M., De Mazière, M., Demoulin, P., Duchatelet, P., Dupuy, E., Hannigan, J., Höpfner, M., Glatthor, N., Griffith, D. W. T., Jin, J. J., Jones, N., Jucks, K., Kuellmann, H., Kuttippurath, J., Lambert, A., Mahieu, E., McConnell, J. C., Mellqvist, J., Mikuteit, S., Murtagh, D. P., Notholt, J., Piccolo, C., Raspollini, P., Ridolfi, M., Robert, C., Schneider, M., Schrems, O., Semeniuk, K., Senten, C., Stiller, G. P., Strandberg, A., Taylor, J., Tétard, C., Toohey, M., Urban, J., Warneke, T., and Wood, S.: Validation of
ACE-FTS $\mathrm{N}_{2} \mathrm{O}$ measurements, Atmos. Chem. Phys., 8, 47594786, https://doi.org/10.5194/acp-8-4759-2008, 2008.

Sullivan, J. T., McGee, T. J., Sumnicht, G. K., Twigg, L. W., and Hoff, R. M.: A mobile differential absorption lidar to measure sub-hourly fluctuation of tropospheric ozone profiles in the Baltimore-Washington, D.C. region, Atmos. Meas. Tech., 7, 3529-3548, https://doi.org/10.5194/amt-7-3529-2014, 2014.

Thompson, A. M., Witte, J. C., McPeters, R. D., Oltmans, S. J., Schmidlin, F. J., Logan, J. A., Fujiwara, M., Kirchhoff, V. W. J. H., Posny, F., Coetzee, G. J. R., Hoegger, B., Kawakami, S., Ogawa, T., Johnson, B. J., Vömel, H., and Labow, G.: Southern Hemisphere ADditional Ozonesondes (SHADOZ) 19982000 tropical ozone climatology. 1. Comparison with TOMS and ground-based measurements, J. Geophys. Res., 108, 8238, https://doi.org/10.1029/2001JD000967, 2003.

Thompson, A. M., Miller, S. K., Tilmes, S., Kollonige, D. W., Witte, J. C., Oltmans, S. J., Johnson, B. J., Fujiwara, M., Schmidlin, F. J., Coetzee, G. J. R., Komala, N., Maata, M., bt Mohamad, M., Nguyo, J., Mutai, C., Ogino, S-Y., Raimundo Da Silva, F., Paes Leme, N. M., Posny, F., Scheele, R., Selkirk, H. B., Shiotani, M., Stübi, R., Levrat, G., Calpini, B., Thouret, V., Tsuruta, H., Valverde Canossa, J., Vömel, H., Yonemura, S., Andrés Diaz, J., T. Tan Thanh, N., and Thuy Ha, H. T.: Southern Hemisphere Additional Ozonesondes (SHADOZ) ozone climatology (2005-2009): Tropospheric and tropical tropopause layer (TTL) profiles with comparisons to OMI based ozone products, J. Geophys. Res., 117, D23301, https://doi.org/10.1029/2011JD016911, 2012.

Thompson, A. M., Witte, J. C. , Sterling, C. Jordan, A. Johnson, B. J., Oltmans, S. J. Fujiwara, M., Vömel, H., Allaart, M., Piters, A., Coetzee, G. J. R., Posny, F., Corrales, E., Andres Diaz, J.,Félix, C., Komala, N., Lai, N., Maata, M., Mani, F., Zainal, Z., Ogino, S-Y., Paredes, F., Luiz BezerraPenha, T., Raimundo da Silva, F., Sallons-Mitro, S., Selkirk, H. B., Schmidlin, F. J., Stuebi, R., and Thiongo, K.: First reprocessing of Southern Hemisphere Additional Ozonesondes (SHADOZ) Ozone Profiles (1998-2016). 2. Comparisons with satellites and ground-based instruments, J. Geophys. Res., 122, 13000-13025, https://doi.org/10.1002/2017JD027406, 2017.

Thorne, P. W., Madonna, F., Schulz, J., Oakley, T., Ingleby, B., Rosoldi, M., Tramutola, E., Arola, A., Buschmann, M., Mikalsen, A. C., Davy, R., Voces, C., Kreher, K., De Maziere, M., and Pappalardo, G.: Making better sense of the mosaic of environmental measurement networks: a system-of-systems approach and quantitative assessment, Geosci. Instrum. Method. Data Syst., 6, 453-472, https://doi.org/10.5194/gi-6-453-2017, 2017.

Vanicek, K., Frei, T., Litynska, Z., and Schmalwieser, A.: UV-Index for the Public, COST-713 Action (UV-B Forecasting), Office for Official Publications of the European Communities, Luxembourg, 27 pp., 2000.

Williams, W. J., Kosters, J. J., Goldman, A., and Murcray, D. G.: Measurement of the stratospheric mixing ratio of $\mathrm{HCl}$ using infrared absorption technique, Geophys. Res. Let., 4, 383-385, https://doi.org/10.1029/GL003i007p00383, 1976. 
Witte, J. C., Thompson, A. M., Smit, H. G. J., Fujiwara, M., Posny, F., Coetzee, G. J. R., Northam, E. T., Johnson, B. J., Sterling, C. W., Mohammed, M., Ogino, S-Y., Jordan, A., Raimundo daSilva, F., and Zainal, Z.: First reprocessing of Southern Hemisphere ADditional OZonesondes (SHADOZ) profile records (19982015) 1: Methodology and evaluation, J. Geophys. Res., 122, 6611-6636, https://doi.org/10.1002/2016JD026403, 2017.

Wolff, M. A., Kerzenmacher, T., Strong, K., Walker, K. A., Toohey, M., Dupuy, E., Bernath, P. F., Boone, C. D., Brohede, S., Catoire, V., von Clarmann, T., Coffey, M., Daffer, W. H., De Mazière, M., Duchatelet, P., Glatthor, N., Griffith, D. W. T., Hannigan, J., Hase, F., Höpfner, M., Huret, N., Jones, N., Jucks, K., Kagawa, A., Kasai, Y., Kramer, I., Küllmann, H., Kuttippurath, J., Mahieu, E., Manney, G., McElroy, C. T., McLinden, C., Mébarki, Y., Mikuteit, S., Murtagh, D., Piccolo, C., Raspollini, P., Ridolfi, M., Ruhnke, R., Santee, M., Senten, C., Smale, D., Tétard, C., Urban, J., and Wood, S.: Validation of $\mathrm{HNO}_{3}, \mathrm{ClONO}_{2}$, and $\mathrm{N}_{2} \mathrm{O}_{5}$ from the Atmospheric Chemistry Experiment Fourier Transform Spectrometer (ACE-FTS), Atmos. Chem. Phys., 8, 3529-3562, https://doi.org/10.5194/acp-8-3529-2008, 2008. 